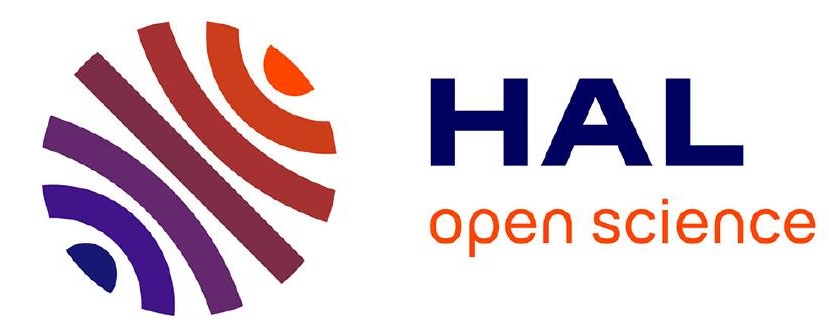

\title{
Snails in depth: Integrative taxonomy of Famelica, Glaciotomella and Rimosodaphnella (Conoidea: Raphitomidae) from the deep sea of temperate Australia
}

Francesco Criscione, Anders Hallan, Nicolas Puillandre, Alexander Fedosov

\section{- To cite this version:}

Francesco Criscione, Anders Hallan, Nicolas Puillandre, Alexander Fedosov. Snails in depth: Integrative taxonomy of Famelica, Glaciotomella and Rimosodaphnella (Conoidea: Raphitomidae) from the deep sea of temperate Australia. Invertebrate Systematics, 2021. hal-03477619

\author{
HAL Id: hal-03477619 \\ https://hal.science/hal-03477619
}

Submitted on 13 Dec 2021

HAL is a multi-disciplinary open access archive for the deposit and dissemination of scientific research documents, whether they are published or not. The documents may come from teaching and research institutions in France or abroad, or from public or private research centers.
L'archive ouverte pluridisciplinaire $\mathbf{H A L}$, est destinée au dépôt et à la diffusion de documents scientifiques de niveau recherche, publiés ou non, émanant des établissements d'enseignement et de recherche français ou étrangers, des laboratoires publics ou privés. 


\section{Iill! Invertebrate csino Systematics}

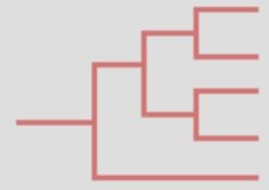

Snails in depth: Integrative taxonomy of Famelica, Glaciotomella and Rimosodaphnella (Conoidea: Raphitomidae) from the deep sea of temperate Australia

\begin{tabular}{|r|l|}
\hline Journal: & Invertebrate Systematics \\
\hline Manuscript ID & IS21008.R2 \\
\hline Manuscript Type: & Research paper \\
\hline Author: & n/a \\
\hline Complete List of Authors: & $\begin{array}{l}\text { Criscione, Francesco; Australian Museum Research Institute, Life and } \\
\text { Geoscience } \\
\text { Hallan, Anders; Australian Museum Research Institute, Life and } \\
\text { Geoscience } \\
\text { Puillandre, Nicolas; Museum National d'Histoire Naturelle, Systematique } \\
\text { et Evolution } \\
\text { Fedosov, Alexander; Russian Academy of Sciences }\end{array}$ \\
\hline Keyword: & $\begin{array}{l}\text { Australia, mitochondrial DNA, molecular systematics, Gastropoda, } \\
\text { morphology, species delineation }\end{array}$ \\
\hline
\end{tabular}



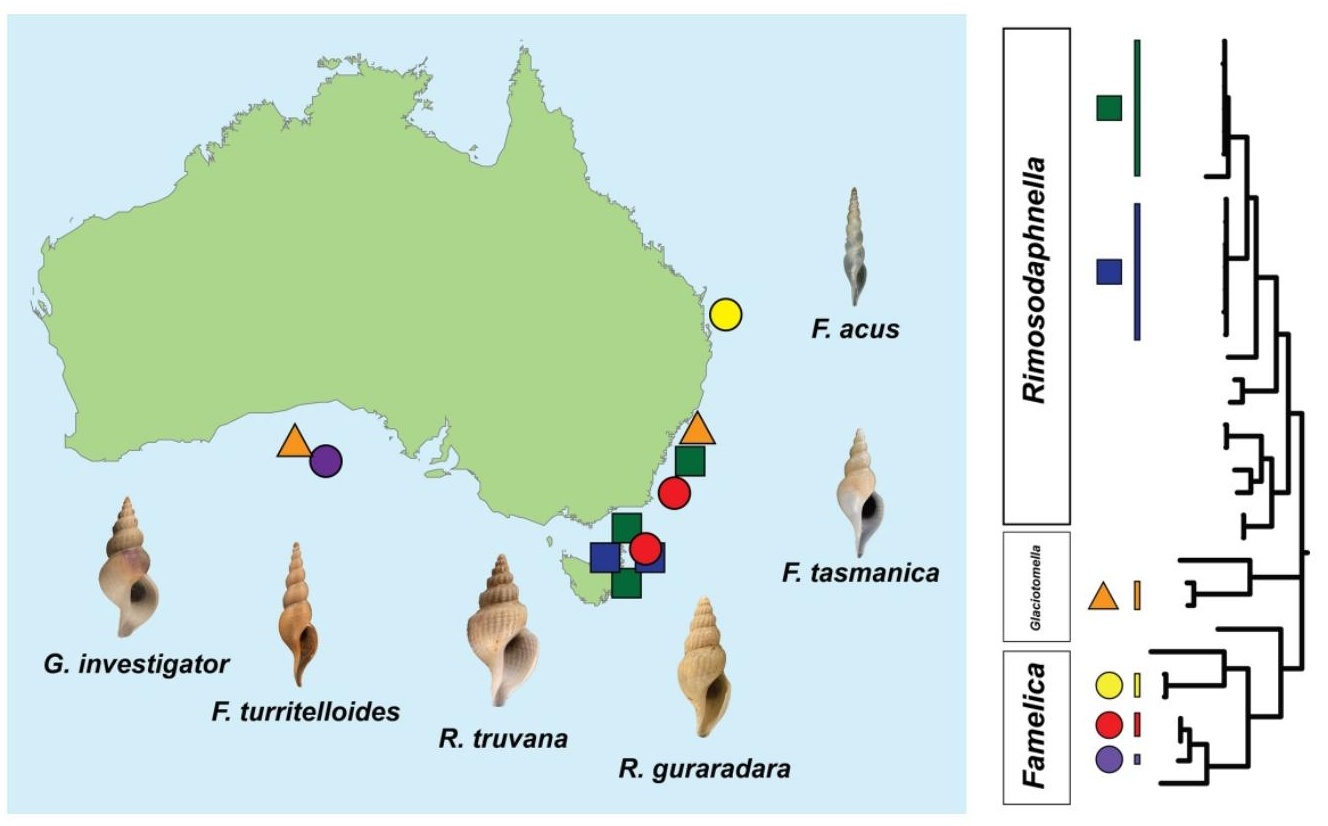

$650 \times 400 \mathrm{~mm}(96 \times 96 \mathrm{DPI})$ 
Short summary

Distribution patterns of deep-sea benthic gastropods remain poorly known, yet such knowledge is crucial to approaching their systematics and understanding their diversity. With focus on the raphitomid genera Famelica, Glaciotomella and Rimosodaphnella, we combine genetic, shell, anatomy and distribution data to identify four new species from Australia and beyond, which we here describe. We identify the set of morphological characters shared by congeneric species and highlight patterns of rarity and endemicity in some species. Our findings suggest that radula and protoconch features are good proxies for genus-level phylogenetic relationships. We discuss the significance of ecological factors (such as choice and availability of preys) as potential drivers in the evolution of this hyperdiverse group of gastropods. 
1 Snails in depth: Integrative taxonomy of Famelica, Glaciotomella and Rimosodaphnella

2 (Conoidea: Raphitomidae) from the deep sea of temperate Australia

3

4

5 Francesco Criscione $\mathrm{A}^{*}$, Anders Hallan ${ }^{\mathrm{A}}$, Nicolas Puillandre ${ }^{\mathrm{B}}$, Alexander Fedosov ${ }^{\mathrm{C}}$

6

7

8

9 A - Australian Museum Research Institute, 1 William Street, Sydney NSW 2010, Australia

B - Institut Systématique Evolution Biodiversité (ISYEB), Muséum National d'Histoire

Naturelle, CNRS, Sorbonne Université, EPHE, Université des Antilles. 57 rue Cuvier, CP 26, 75005 Paris, France

C - A.N. Severtsov Institute of Ecology and Evolution of Russian Academy of Sciences, Leninski Prospect 33, Moscow 119071, Russia

* Corresponding author: francesco.criscione@austmus.gov.au

Running Head: Integrative taxonomy of three raphitomid genera

Keywords: shell, radula, deep sea, mtDNA, species delimitation, biodiversity 


\section{Abstract}

33 The deep sea of temperate south-eastern Australia appears to be a 'hotspot' for diversity 34 and endemism of conoidean neogastropods of the family Raphitomidae. Following a series of expeditions in the region, a considerable amount of relevant DNA-suitable material has become available. A molecular phylogeny based on this material has facilitated the identification of diagnostic morphological characters, allowing the circumscription of monophyletic genera and the introduction of a number of new genus-level taxa. Both named and new genera are presently being investigated through integrative taxonomy, with the discovery of a significant amount of undescribed species. As part of this ongoing investigation, this study focuses on the genera Famelica Bouchet \& Warén, 1980, Glaciotomella Criscione, Hallan, Fedosov \& Puillandre, 2020 and Rimosodaphnella Cossmann, 1914. We subjected a comprehensive mitochondrial DNA dataset of representative deep-sea raphitomids to the species delimitation methods ABGD and ASAP, which recognised 18 and 15 primary species hypotheses (PSHs) respectively. Following additional evaluation of shell and radular features, as well as examination of geographic and bathymetric ranges, nine of these PSHs were converted to secondary species hypotheses (SSHs). Four SSHs (two in Famelica and two in Rimosodaphnella) were recognised as new to science and their formal descriptions are provided herein. 
Introduction

Turriform Conoidea is the most diverse group of marine molluscs (Horton et al. 2019), with considerable species diversity occurring in the deep sea, where it is often coupled with low abundance (Sysoev 1997; Kantor et al. 2008; Bouchet et al. 2009). One of the total fifteen families of the group, Raphitomidae Bellardi, 1875, is among the most poorly studied (Bouchet et al. 2011), notably in the deep sea (Criscione et al. 2021). Because of their high diversity, low abundance and morphological complexity combined, the systematics of many deep-sea genera and species remains tentative, with a large proportion of taxa awaiting description (Bouchet et al. 2009). To further complicate matters, most of the taxonomic accounts available for groups below family level are primarily based on shell morphology (Sysoev and Ivanov 1985; Sysoev and Kantor 1986, 1987; Sysoev 1988, 1990, 1996a, b; Bouchet and Sysoev 1997; Sysoev 1997; Bouchet and Sysoev 2001; Sysoev and Bouchet 2001; Morassi and Bonfitto 2006; Kantor et al. 2012; Stahlschmidt and Chino 2012; Bonfitto and Morassi 2013; Morassi and Bonfitto 2015; Kantor et al. 2016) and only three studies do include molecular data (Fassio et al. 2019; Russini et al. 2020; Criscione et al. 2021). This is partly due to a lack of study material, particularly that suitable for molecular analysis (Criscione et al. 2021). Due to widespread shell homoplasy, some of the earlier studies have incorrectly attributed a considerable number of unrelated species to very few raphitomid genera, colloquially termed 'dumpsters' (such as Pleurotomella Verril, 1872 and Gymnobela Verrill, 1884) (Criscione et al. 2021). Based on their support as clades and on diagnostic morphological characters, Criscione et al. (2021) demonstrated the non-monophyly of such genus-level groups and, in constraining them, introduced a number of new genus-level taxa and described their type species. The same study also revealed a multitude of putatively undescribed species among deep-sea raphitomids of a temperate region roughly corresponding to the central and eastern part of the South Australia realm (\#26 of Costello et al. 2017) and the southern part of the Tropical Australia and Coral Sea realm (\#16 of Costello et al. 2017) (Fig. 1). With nearly half of the currently accepted deep-sea genera (24 out of 50) and nearly a third (7) endemic, this area is a potential 'hot spot' for raphitomid diversity (Criscione et al. 2021). Thanks to recent sampling efforts in the area (Maclntosh et al. 2018; Williams 2018; O'Hara et al. 2020), relatively abundant raphitomid samples, suitable for genetic analysis, are available. This material has allowed studies whose methodological design for species delimitation transcends the mere conchological approach 
of earlier taxonomical accounts and capitalises on the combination of morpho-anatomical and molecular data (i.e. 'integrative taxonomy', Dayrat 2005; Will et al. 2005). As a result of these studies on the Australian Raphitomidae, new species have been described for the genera Gladiobela Criscione, Hallan, Puillandre \& Fedosov, 2020 (5 species) and Pagodibela Criscione, Hallan, Puillandre \& Fedosov, 2020 (2) (Hallan et al. 2021) and of Austrobela Criscione, Hallan, Puillandre \& Fedosov, 2020 (4), Austrotheta Criscione, Hallan, Puillandre \& Fedosov 2020 (1), Spergo Dall, 1895 (4) and Theta Clarke, 1959 (2) (Criscione et al., in press). Based on a larger sampling size, including specimens from beyond Australian waters, this study aims to revisit species delimitation and taxonomy in three genera: Famelica Bouchet \& Warén, 1980, Glaciotomella Criscione, Hallan, Puillandre \& Fedosov 2020 and Rimosodaphnella Cossmann, 1916. In the analysis of Criscione et al. (2021), these genera (along with Veprecula Melvill, 1917) constituted a monophyletic group (clade 'A' of fig. 2 in Criscione et al. 2021). Formal descriptions are here presented for newly recognised species. Furthermore, revised genus diagnoses and new anatomical and morphological data are introduced for both established and new taxa, which are discussed in terms of their diagnostic utility at the genus level. Finally, geographic and bathymetric distributions are presented and discussed for the taxa treated herein. 
Materials and methods

\section{Taxon sampling}

The samples studied herein were selected among all Raphitomidae ethanol-preserved material from the malacological collections of the Australian Museum, Sydney (AMS), the South Australian Museum, Adelaide (SAMA) and the Muséum national d'Histoire naturelle, Paris (MNHN). All studied material has been collected off Australia during the expeditions IN2015_C01, IN2015_C02 (GAB) and IN2017_V03 (Tasman and Coral Seas), targeting (among other sites) a number of Commonwealth Marine Reserves (CMR), and other localities (mainly of the tropical and temperate Indian and Pacific Oceans), during a number of voyages that formed part of the Tropical Deep-sea Benthos programme of MNHN (expeditions.mnhn.fr; Fig. 1, Table S1).

As a result of ongoing systematic research on the Conoidea at the AMS and MNHN, several hundreds of (mostly unpublished) sequences of the mitochondrial gene cytochrome oxidase subunit 1 (cox1) were obtained (see methodology below) from a considerable number of largely undescribed raphitomid taxa. In order to assist with the selection of the study material, a pilot analysis was performed on a dataset including all raphitomid cox1 sequences, using the neighbour-joining method (NJ) (Saitou and Nei 1987) implemented in MEGA 7 (Kumar et al. 2016). In particular, the dataset included cox1 sequences of the holotypes for the type species of several deep-sea raphitomid genera, including Glaciotomella investigator Criscione, Hallan, Puillandre and Fedosov et al. 2020 (GenBank AN: MN983178). The dataset also encompassed cox1 sequences of well-recognisable species, such as Famelica tasmanica Sysoev \& Kantor, 1987, as well as of several Australian undescribed species included in the phylogeny of Criscione et al. (2021), such as those placed in the genus Rimosodaphnella therein. All cox1 sequences of Glaciotomella, Famelica or Rimosodaphnella used in (Criscione et al. 2021) and all sequences that (in the results of the NJ analysis; Fig. S1) were more closely related to the species of these three genera than to any other raphitomid genus, were selected as ingroup and used in the molecular analysis described below (Table S1). Sequences representing 13 raphitomid species from 13 genera were selected as outgroups (Table S1). Their choice was based on the phylogeny of Criscione et al. (2021), containing many southern and south-eastern Australian Raphitomidae . 
Among the ingroup specimens, morphological examination was only conducted on those collected in Australian waters. However, for samples outside Australia, examination of shell photographs was possible and was utilised when necessary and appropriate. Geographic and bathymetric data were available for all ingroup specimens. Geographic distributions were assessed with reference to marine biogeographic realms as delimited in Costello et al. (2017). According to Bouchet et al. (2008), when inferring bathymetric distributions of species from sampling depth intervals, only shallower depth values were considered, as there is no evidence that the species collected occurs beyond that value.

Molecular methods

Molecular work was performed in laboratories at two different institutions (AMS and MNHN). Unless otherwise stated, the same methodology was followed by both laboratories. DNA was extracted from small pieces of foot muscle by use of a Bioline Isolate II Genomic DNA extraction kit for animal tissue, following the standard procedure of the manual (AMS) or using the Epmotion 5075 robot (Eppendorf), following the recommendations by the manufacturer (MNHN). A fragment of cox1 was amplified using the primer pairs LCO1490/HCO2198 for cox1 (Folmer et al. 1994). PCR reactions were performed in volumes of $25 \mu \mathrm{l}$, containing $3 \mathrm{ng}$ DNA, 1X Qiagen CoralLoad PCR Buffer, 2.5mM MgCl2, 0.25mM dNTP, $0.5 \mathrm{mM}$ of each primer, $0.5 \mu \mathrm{g} / \mu \mathrm{l}$ of BSA and $0.2 \mu \mathrm{l}$ of Bioline MyTaq DNA polymerase. Amplification consisted of an initial denaturation step at $94^{\circ} \mathrm{C}$ for $4 \mathrm{~min}$, followed by 37 cycles of denaturation at $94^{\circ} \mathrm{C}$ for $30 \mathrm{~s}$, annealing at $50^{\circ} \mathrm{C}$ for $30 \mathrm{~s}$, followed by extension at $72^{\circ} \mathrm{C}$ for $1 \mathrm{~min}$. The final extension was at $72^{\circ} \mathrm{C}$ for $5 \mathrm{~min}$. PCR products were purified and sequenced by the Macrogen (AMS) and Eurofins (MNHN) sequencing facilities. When necessary, chromatograms were manually corrected for misreads and forward and reverse strands were merged into one sequence file using CodonCode Aligner v. 9.0.1 (CodonCode Corporation, Dedham, MA). Sequence alignments were generated using MUSCLE as implemented in MEGA7 (Kumar et al. 2016). Sequences were deposited in GenBank (Table S1). Phylogenetic trees were generated using Maximum Likelihood (ML) and Bayesian inference (BI) methods. ML was performed using the program IQ-Tree v. 2.1.1 (Minh et al. 2020), including the implemented model-finder function (Kalyaanamoorthy et al. 2017) and ultrafast bootstrapping (BS, 1000 replicates) (Hoang et al. 2017). The BI analysis was performed in MrBayes 3.2.6 (Ronquist and Huelsenbeck 2003) and included 2 runs of $10^{7}$ 
generations, with 4 chains each and a sampling frequency of one tree per 1000 generations. Other parameters were set to default. After checking for convergence (ESS>200) with Tracer (Rambaut et al. 2018), a consensus tree was calculated after discarding the first $25 \%$ trees as burn-in. According to MrBayes manual (p. 94), a priori model testing was not performed, and the $\mathrm{GTR}+\mathrm{G}+\mathrm{I}$ model was applied to the BI analysis. Nodal support was assessed as Bayesian posterior clade probabilities (BPP). Pairwise genetic distances were calculated for cox1 sequences using the Kimura-2 parameter model (K2p, Kimura 1980) as implemented in MEGA7 with the option 'pair-wise deletion of gaps'.

Morphological examinations

All studied samples consisted of animals and shells, from which they had been extracted following the methodology described in Criscione et al. (2021). We studied shell morphology and (when possible) internal anatomy, including radular morphology. Shells of sequenced specimens were affixed to plasticine and positioned with their vertical axis parallel to the observation plane. Each shell was then photographed from above using a digital SLR camera. Maximum shell length (SL) and width (SW) were measured on digitised images using the calibrated ruler tool in Adobe Photoshop CC v.20.0.6. Measurements were rounded to the nearest $0.1 \mathrm{~mm}$. The number of shell whorls was counted under a Leica MZ8 stereomicroscope, according to Bouchet and Kantor (2004). While it was possible to count the number of teleoconch whorls for almost all studied specimens, protoconch whorls could only be counted occasionally due to widespread erosion of the apex. Anatomical studies were conducted on animals removed from ethanol and briefly rehydrated in distilled water. Using standard dissection tools, the venom apparatus was excised and the radular sac isolated and placed on a glass slide; during this dissection process, head-foot, mantle, genital and (non-radula) foregut characters were examined where possible. After dissolution in dilute commercial bleach, clusters of hypodermic teeth were rinsed repeatedly in distilled water, then separated into individuals and ligament-connected pairs/smaller clusters. Subsequently, the glass stub was affixed to a carbon adhesive placed on a $12 \mathrm{~mm}$ diameter aluminium mount. All samples were imaged at Macquarie University, Sydney, using a Phenom XL Scanning Electron Microscope. 
Firstly, the Automatic Barcode Gap Discovery (ABGD, Puillandre et al. 2012a; https://bioinfo.mnhn.fr/abi/public/abgd/abgdweb.html) was used with a p-distance model, the relative gap width $(X)$ set to 1 and the other parameters left to default.

Secondly, the Assemble Species by Automatic Partitioning (ASAP, Puillandre et al. 2020; https://bioinfo.mnhn.fr/abi/public/asap/) was applied. Similar to ABGD, ASAP proposes species partitions based on genetic distances only; however, ASAP screens all the genetic distances from the lowest to the highest and merges sequences into "groups" that are successively further merged until all sequences form a single group. At each merging step, the partition is evaluated and given a score. At the end of the analyses, the 10 partitions with the lowest scores are provided (the lower the ASAP-score, the better the partition). Resulting ABGD and ASAP groups were considered primary species hypotheses, henceforth referred to as PSHs. Following Puillandre et al. (2012b), conversion of PSHs to secondary species hypotheses (SSHs) was conducted through comparative examination of morphological characters as well as through evaluation of geographic and bathymetric data and phylogenetic reconstruction based on the DNA sequences. In particular, when converting an individual PSH to $\mathrm{SSH}$, the occurrence of the following conditions was assessed: (i) the PSH is a highly supported clade (BPP>0.98 and BS>90\%), (ii) all its constituent specimens share at least one distinctive morphological feature deemed not to be polymorphic or ecophenotypic and without exhibiting intermediate forms, (iii) the PSH maintains genetic or morphological divergence and/or bathymetric partitioning when occurring in sympatry with another PSH. When available, species names were assigned to SSHs based on the current taxonomy. New species names were introduced when no names were available. Formal descriptions for these taxa are given in the systematics section below. 
218 Results

219 Molecular studies

220 Molecular analyses were based on a total of 46 cox1 sequences (28 newly produced and 18

221 GenBank-sourced). Of the total sequences employed, 33 constituted the ingroup and the

222 remaining 13 were used as outgroups.

223 In the vicinity of the barcode gap (i.e. between 0.8 and 3.3\%, the highest intra-PSH genetic

224 distance and the lowest inter-PSH genetic, respectively), the ABGD analysis of the cox1

225 ingroup dataset consistently returned a primary partition with eighteen groups of

226 sequences (PSHs). Among all PSHs, six (F1, F3, G1, G2, R1, R2) contained exclusively

227 Australian samples, one (F2) included samples from Australian seas and beyond, while the remaining eleven (F4, FA, GA, R3-R5, RA-RE) encompassed sequences from outside

229 Australian waters.

230 The best ASAP partition (i.e. with the lowest ASAP-score) returned 15 PSHs, 12 of which were identical to those resulting from $A B G D$ and the remaining three corresponding to the combinations $F 1+F 3, G 1+G 2$ and R4+R5. The second-best ASAP partition included 14 PSHs, with RD and RE grouped (when compared to the 15-species ASAP partition). The ASAP-score of the alternative partitions were much higher and are thus ignored. The $\mathrm{BI}$ and $\mathrm{ML}$ analyses generated trees (Fig. 2, S2) with similar topologies and no supported incongruences. Clades representing PSH-level relationships and above were generally wellsupported, with very few exceptions. In both analyses, three major genus-level clades were retrieved, namely Famelica ( $\mathrm{BPP}=1, \mathrm{BS}=95 \%)$, Glaciotomella $(\mathrm{BPP}=1$ and $\mathrm{BS}=95 \%$ ) and Rimosodaphnella (BPP=0.98 and $\mathrm{BS}=94 \%$ ). These three clades included five, three and ten ABGD PSHs respectively, all forming highly supported (in terms of nodal support) and welldifferentiated (in terms of branch lengths) clades. The only exception was R1, which received no support from the $\mathrm{BI}$ analysis and moderate support from the $\mathrm{ML}$ analysis (BS=95\%). ASAP PSHs R4+R5 and G1+G2 were highly supported by both analyses (Fig. 2, S2), while $\mathrm{F} 1+\mathrm{F} 3$ received no support. Within the genus-level clades, there was no overlap between intra- and inter-ABGD-PSH distances. In the Famelica clade, the intra-PSH pairwise distance in cox1 measured for the only PSH with more than one sample (F2) was $0.8 \%$, with inter-PSH distances ranging from 5.2 to $18.2 \%$ (average=14.5\%) (Table 1 ). The lowest inter-PSH distances were observed between F1 and F3 (the two ABGD-PSH grouped by ASAP). No intra-ABGD-PSH pairwise 
distances could be measured for the Glaciotomella clade and the inter-PSH distances ranged from 3.3 to $16.0 \%$ (average=9.7\%), with the lowest value recorded between G1 and G2 (the two ABGD-PSH grouped by ASAP). In the Rimosodaphnella clade, the intra-PSH pairwise distances in cox 1 ranged from 0 to $0.3 \%$ (average $=0.2 \%$ ) with inter-PSH distances ranging from 4.6 to $15.6 \%$ (average=11.7\%) (Table 2). The lowest inter-PSH distances were observed between R4 and R5 (the two ABGD-PSH grouped by ASAP) and the highest intraPSH distances were found within R2. The genetic distance between RD and RE, the two ABGD-PSH grouped in the second-best ASAP partition, is $6.7 \%$.

\section{Morphological studies}

Shell morphology was examined for all sequenced material and internal anatomy, including radular morphology (when possible) for at least two sequenced specimens per PSH. Detailed morpho-anatomical observations refer to PSHs examined herein, and do not include PSHs assigned with a letter suffix (i.e., FA, GA, etc.). Protoconchs of many specimens were considerably eroded and could therefore not be studied. For the remaining specimens, some sculptural detail could be inferred from heavily eroded protoconchs by careful examination using a microscope. However, owing to their very poor quality, these protoconchs are not figured herein. When observed, protoconch sculpture was highly conserved within each genus-level clade and could not be used to differentiate congeneric PSHs. While Rimosodaphnella PSHs possessed a protoconch with a typical raphitomid diagonally cancellate sculpture (Fig. 3C), Famelica and Glaciotomella PSHs exhibited a protoconch with median keel as the only spiral element (Fig. 3A-B). In these two genera, axial elements ('pillars' in Bouchet et al. 2011, p. 283) were present, that were restricted to the area below the keel in Famelica (Fig. 3A) and extended also above the keel in Glaciotomella (Fig. 3B).

All PSHs in the Famelica clade exhibited a gross shell morphology and whorl profile that were comparatively similar (Figs 4-5), with only one (F4) differing in its sculptural elements (prominent spiral keels). The radula was absent in all Famelica specimens studied.

Very similar shells were exhibited by PSHs in the Glaciotomella clade (Fig. 6), with shells of G1 and $G 2$ being remarkably larger than GA and sharing the same sculptural pattern. While the radula of GA was not studied, G1 and G2 shared nearly identical hypodermic teeth (Fig. $6)$. 
Rimosodaphnella PSHs varied notably in shell morphology (Figs 7-8), from comparatively large and broad (R2, Fig. 7D-F), to large and elongate (R1, Fig. 7A-C), to very small (e.g. R4 and R5, Fig. 8B-C). Generally, axial sculpture was more prominent than spiral sculpture in all shells of all PSHs, with two exceptions: RA, where axials were absent (Fig. 5C) and R2, where spiral and axial elements were equally prominent (Fig. 7G). The radula of both R1 and R2 (Fig. 10) consisted of similar straight, unbarbed hypodermic teeth that in R2 were shorter and broader.

\section{Geographic and bathymetric distributions}

The Famelica clade is recorded from at least four marine realms (sensu Costello et al. 2017) (Fig. 1A), the Glaciotomella clade from three (Fig. 1A) and the Rimosodaphnella clade from at least six marine realms (Fig. 1B). Famelica and Rimosodaphnella both exhibit a wide bathymetric range (respectively 398-4144 $\mathrm{m}$ and 350-4750 $\mathrm{m}$ ), while the range of Glaciotomella (600-2474 m) is narrower (Fig. 11). In Famelica, the sister PSHs F1 and F3 are known only from off Australia, where they are found respectively at bathyal and abyssal depths of the east coast (Fig. 1A). F2 is known from two widely separated localities, both geographically (Fig. 1A) and bathymetrically (Fig. 11), namely in the temperate GAB (3389 $\mathrm{m})$ and off the tropical New Caledonia $(815 \mathrm{~m})$. The only samples of the remaining Famelica PSHs, F4 (Papua New Guinea, PNG - 398 m; Figs 1A, 8) and FA (Taiwan - 999 m; Figs 1A, 11), were collected outside the seas of Australia.

Two of the three ABGD PSHs of Glaciotomella, G1 and G2, are found only off temperate Australia (albeit G1 at the temperate-tropical boundary) at comparable depths (2474 and $2007 \mathrm{~m}$ ). The remaining PSH, GA is only known from a single record in shallower waters (600 m) off the Solomon Islands.

For Rimosodaphnella, virtually all records of the only two Australian PSHs, R1 and R2, are limited to a relatively restricted area off the east coast of Tasmania (Fig. 1B), where they occupy fairly disjunct bathymetric ranges (bathyal vs. abyssal; Fig. 11). The only sample of RA is found off the south coast of Chile (Fig. 1B) in much shallower waters (766 m, Fig. 11). All other Rimosodaphnella ABGD PSHs occur at lower latitudes in the warmer and shallower waters of the Philippines (R4 and R5; Figs 1B, 11), Melanesia (R3, RB, RC; Figs 1B, 11) and Polynesia (RD and RE; Figs 1B, 11). 
PSH to SSH conversion

Comparative examination of the morphological, geographic and bathymetric data available was employed to attempt the conversion of PSHs to SSHs. As generating morphological data for most species with distribution outside Australian waters was beyond the scope of this study, testing of seven PSHs (i.e. FA, GA, RA-RE), out of the total retrieved by ABGD and ASAP, was not attempted and these are pending further sampling and taxonomic investigation. As detailed below, nine of the PSHs retrieved by ABGD and ten of those retrieved by ASAP satisfied at least one of the conditions described in the methodological section. It must be noted that some of the PSHs consisted of one single sequence and, for those, support value and intra-PSH genetic distance were not available. Also, the information available on their geographic and bathymetric distribution was limited to a single collection event. The evidence for PSHs to SSHs conversion is detailed below, where congeneric PSHs are compared with each other according to their relationships as resolved by the molecular analysis (Figs 2 and S2). Two haplotypes of the Famelica clade represent two distinct ABGD PSHs (F1 and F3) but are combined into one $(\mathrm{F} 1+\mathrm{F} 3)$ by ASAP. While the comparatively low genetic distance separating them (5.2\%) could be interpreted as an indication of genetic connectivity between two allopatric conspecific populations (Fig. 1A), this is not sufficient to convert $\mathrm{F} 1+\mathrm{F} 3$ to $\mathrm{SSH}$, as criteria (i) and (ii) are not met. In fact, F1+F3 is not statistically supported (Figs 2, S2) and there is considerable difference between F1 and F3 in shell features (with F1 possessing a much more slender and darker shell; Fig. 4A, D-F). For these reasons F1 and F3 (as delimited by ABGD) are converted into two separate SSHs. The only Famelica PSH including more than one sample, F2, exhibited a value of intra-PSH genetic distance $(0.8 \%)$ considerably lower than the distance value $(13.8 \%)$ separating it from its closest relative, F4. In addition, F2 and F4 differ significantly in shell features (Fig. 5C, F-G) and occur at different depths in distinct geographic areas (Figs 1, 11), which clearly suggests that they should be treated as separate SSHs. Two sequences in the Glaciotomella clade are treated as distinct PSHs by ABGD (G1 and G2) but are combined into one highly supported PSH (G1+G2; BPP=1, BS=100\%; Figs 2, S2) by ASAP. G1 and G2 are found in allopatry, they are separated by comparatively low genetic distance (3.3\%), have very similar shells (Fig. 6A-B), and in terms of observed anatomical characters differ only in $\mathrm{G} 2$ exhibiting a peculiar squamose osphradium. Whether the latter 
character is of any taxonomic value or a result of a developmental anomaly is not clear, therefore the evidence available is interpreted as supporting combination of G1 and G2 (as suggested by ASAP) and subsequent conversion to a single SSH. In the Rimosodaphnella clade, R1 was separated from its most closely related PSH (RA) by comparatively large genetic distance (6.4\%; Table 2 ) and could be differentiated by its more pronounced cancellate shell sculpture (Fig. 7A-C). R1 occurs in a very distant realm (Fig. 1B) at a different depth (Fig. 11). For these reasons, and despite the comparatively low support $(\mathrm{BPP}=0.71, \mathrm{BS}=96 \%)$ received in the molecular analysis (Figs 2, S2), R1 is converted into SSH. R2 fulfils all criteria necessary to be converted to SSH. This PSH is separated from its closest relatives (R1 and RA) by high genetic distance (9.3 and 6.4\%; Table 2), far higher than its intra-PSH genetic distance (0.3\%). It has a notably different shell (Fig. 7D-F) and it is found in sympatry with R1 in the South Australian realm (Fig. 1B) at deeper sites (Fig. 11). $R 3$, sister to the R1+RA+R2 clade, is separated from each of these by high genetic distance (Table 1) and differs considerably in shell shape and sculpture (Fig. 8E). It is allopatric to RA, R1 and R2 (Fig. 1B) and is found at much shallower depth than the two latter PSHs (Fig. 11). Due to its marked genetic and morphological distinctiveness and distinct bathymetric distribution, $\mathrm{R} 3$ is converted to $\mathrm{SSH}$. R4 and R5 were recognised by ABGD only, while ASAP combined them into a single PSH (R4+R5). Their members exhibit very similar shells (Fig. 8B-C) and are separated by the lowest inter-PSHs distance (4.6\%) measured for PSHs of Rimosodaphnella. They also occur sympatrically (Fig. 1B) and at comparable depth (Fig. 11). As no genetic, morphological, geographic or bathymetric criterion can be applied to reliably distinguish them, they are here combined (as indicated by ASAP) into a single SSH.

Assigning names to $\mathrm{SSH}$

A search was conducted for all names available and potentially applicable to the nine SSHs resulting from the conversion process described above. By consulting the relevant literature on Raphitomidae (Dall 1881; Watson 1881; Verrill 1884; Dautzenberg and Fischer 1896; Schepman 1913; Barnard 1963; McLean and Poorman 1971; Bouchet and Warén 1980; Sysoev and Kantor 1987; Sysoev 1990, 1996b; Figueira and Absalão 2012; Bonfitto and Morassi 2013; Criscione et al. 2021) and by comparison of molecular and morphological data available on type specimens with the data generated on sequenced specimens, we 
378 found five names applicable to five SSHs. One SSH, G1+G2, including the holotype of $G$.

379 investigator, could be readily assigned to this species. As the constituent specimens of F3,

$380 \mathrm{~F} 4, \mathrm{R} 3$ and R4+R5 shared shells that closely resembled the holotypes of respectively

381 Famelica tasmanica Sysoev \& Kantor 1987 (Fig. 4D), Veprecula polyacantha Stahlschmidt,

382 Chino \& Kilburn 2012 (Fig. 5G), Rimosodaphnella solomonensis Bonfitto \& Morassi 2013 (Fig.

383 8D) and R. brunneolineata Bonfitto \& Morassi 2013 (Fig. 8A), these SSH were attributed to

384 these taxa. This required the formal transfer (as hereby proposed) of the latter species to

385 Famelica as Famelica polyacantha (Stahlschmidt, Chino \& Kilburn, 2012) n. comb. As no

386 available names could be found for the remaining four SSHs, these were assigned to new

387 taxa: namely Famelica turritelloides n. sp. (F1), F. acus n. sp. (F2), Rimosodaphnella

388 guraradara n. sp. (R1) and R. truvana n. sp. (R2). Formal taxonomic descriptions of these

389 newly recognised species are provided below. 


\section{Systematics}

General remarks

If not stated otherwise, holotypes are dissected ethanol-preserved specimens, and all systematic descriptions are based on the holotype. Shell whorls counts (approximated to one decimal unit) are reported with reference to intact whorls only. When applicable, the expression 'at least' is used in combination with the whorl count to indicate potential additional missing whorls that could not be counted. Shell and head-foot colouration reported in the descriptions is based on observations performed prior to fixation and thus may not be fully reflected in the illustrations provided (Figs 3-8).

Measurements of radular features, mainly the length of the adapical opening and the dorsal blade, are given as ratios of the length of the shaft. The 'shaft' is here defined as the entire length of the tooth minus the base, where there is a notable swelling and angulation that clearly differentiates it from the comparatively thin-walled hypodermic, rolled structure. This is done to ensure consistency with the terminology used in Criscione et al. (2021).

\section{Superfamily Conoidea Fleming, 1822}

Family Raphitomidae Bellardi, 1875

Genus Famelica Bouchet \& Waren, 1980

Type species: Pleurotomella catharinae Verrill \& S. Smith [in Verrill], 1884 by subsequent designation by Bouchet and Warén (1980).

\section{Diagnosis}

Shell narrowly fusiform to turriform with very high spire, thin- or very thin-walled, often translucent. Protoconch pagodiform, multispiral, of four to five dark orange whorls, three to four of which bearing a median keel, with orthocline axial pillars below the keel and no sculpture above. Teleoconch of up to seven evenly convex, uniformly dark orange, cream to white transparent whorls. Subsutural ramp indistinct, or well-pronounced, steep to very steep, narrow to moderately wide. Shell base convex, often clearly demarcated from long, slender siphonal canal with deep to moderate concavity. Spiral sculpture of densely set rounded subequal cords, or (rarely)of a pair of sharp prominent median keels. Axial sculpture of very fine collabral growth lines. Aperture elongate, a half to less than one third 
of shell length. Outer lip thin, finely sculptured; inner lip smooth, with or without very thin callus. Anal sinus moderately deep, U-shaped. Radula, and venom apparatus absent. Animal with broad to long, narrow funnel; cephalic tentacles moderately short, cylindrical to weakly tapering, with small eyes situated at their lower portion not recorded. Rhynchocoel capacious.

\section{Remarks}

Famelica is characterised by the combination of: (a) a multispiral keeled protoconch with axial pillars below the keel (this study, Fig. 3A; Bouchet and Warén 1980, p. 88-90, figs 277281; Figueira and Absalão 2012, fig. 4), (b) a very slender, thin-walled and spirally sculptured teleoconch (this study, Figs 4-5; Dall 1889, p. 117, pl. 10, fig. 12; Barnard 1963, fig. 1b; Bouchet and Warén 1980, figs 186-189; Sysoev and Kantor 1987, figs а-д; Sysoev 1990, pl. 2, fig. 8; 1996b, figs 28-29; Figueira and Absalão 2012, fig. 3) and (c) absence of radula, proboscis and venom gland (Criscione et al. 2021). This combination of morpho-anatomical characters is unique among the Raphitomidae (Criscione et al. 2021). The distinctive protoconch morphology of Famelica is shared by only one other deep-sea raphitomid genus, the monotypic Aliceia Dautzenberg and Fischer, 1897 (Dautzenberg and Fischer 1897, p. 182, pl. 4, fig. 16; Bouchet and Warén 1980, p. 90, fig. 230; Figueira and Absalão 2012, p. 5, fig. 2). Although its type species, $A$. aenigmatica Dautzenberg and Fischer, 1897, exhibits a very distinctive shell, with a labial process and a deep umbilicus (Dautzenberg and Fischer 1897, p. 182, pl. 4, fig. 15, 17-18; Bouchet and Warén 1980, p. 90, fig. 190; Figueira and Absalão 2012, p. 5, fig. 2), its overall shape and whorl profile are not too dissimilar from those of some species of Famelica (e.g. F. bitrudis (Barnard, 1963). No anatomical details are available for Aliceia, including information on the presence of a radula. Their remarkable similarity may suggest a close phylogenetic relationship between Aliceia and Famelica. However, testing of this hypothesis depends on the availability of live-collected material of A. aenigmatica for molecular and anatomical investigation.

Prior to this study, Famelica included ten Recent species: the type species $F$. catharinae (Verrill \& S. Smith [in Verrill], 1884) (Fig. 4B), F. monoceros (R. B. Watson, 1881), F. mirmidina (Dautzenberg \& H. Fischer, 1896), F. monotropis (Dautzenberg \& H. Fischer, 1896) (Bouchet and Warén 1980 figs 187, 188 and 189 respectively) and F. scipio (Dall, 1889) (Dall 1889 pl. 10, fig. 12) from the Atlantic; F. bitrudis (Barnard, 1963) (Barnard 1963, fig. 1b; 
Sysoev 1996b, figs 28-29) and F. tajourensis Sysoev \& Kantor, 1987 (Fig. 5B) from the Indian Ocean as well as F. pacifica Sysoev \& Kantor, 1987 (Fig. 4C), F. nitida Sysoev, 1990 (Fig. 5A) and F. tasmanica Sysoev \& Kantor, 1987 (Fig. 4D) from the Pacific Ocean. Of these species, only the latter was included in the molecular analysis of this study (Fig. 2, S2) and no molecular data is available for the other species, including the type species. With the inclusion of the two new species described below (F. turritelloides n. sp. and F. acus n. sp.) as well as the transfer of a further species (F. polyacantha n. comb.), thirteen species now comprise the genus, occurring from bathyal to abyssal depth in all of the world's oceans. Most species have very similar shell morphology and sculpture, with the exception of $F$. tajourensis, possessing a protoconch with axial pillars extending above the keel (Sysoev and Kantor 1987, fig. ж). This species exhibits an unusual pagodiform teleoconch whorl profile (Fig. 5B), which is shared with F. monotropis (Bouchet and Warén 1980 fig. 189). The notably shorter siphonal canal and absence of spiral sculpture of $F$. nitida (Fig. 5A) and the prominent keels of $F$. polyacantha (Fig. 5F-G), represent a further departure from the typical genus shell morphology. While our results (Fig. 2, S2) show that the latter species belongs to Famelica, further study is required to confirm the generic attribution of the remaining taxa, clarify status of putative new species (e.g. FA) and elucidate the phylogenetic relationships within Famelica.

Material examined m (AMS C.482253). COI: MN983170.

Distribution

Known only from the type locality.

483 For the turreted shape of its shell, vaguely resembling that of the unrelated 
ZooBank registration

http://zoobank.org/urn:Isid:zoobank.org:act:69A31671-72A6-45E1-9048-1A04352BB83E

\section{Description}

Shell ( $S L=23.3, S W=6.4 \mathrm{~mm}$ ) thin-walled, elongate-fusiform to turriform with strongly convex whorls and long, slender siphonal canal. Protoconch pagodiform, multispiral, of at least 3 whorls, all bearing a median keel, with axial pillars below keel and no sculpture above. Teleoconch of 6.5 strongly convex, uniformly dark cream whorls. Suture adpressed; subsutural ramp steep, moderately wide. Spiral sculpture of fine, regularly set rounded cords (14 on penultimate whorl, 32 on last whorl). Axial sculpture of very fine collabral growth lines, most distinct on subsutural ramp, and below - in interspaces between spiral cords. Shell base convex, with pronounced concavity at its transition to long, undulating siphonal canal. Aperture moderately wide; aperture length less than one third of shell length. Outer lip thin, unsculptured, inner lip smooth, with very thin callus. Anal sinus moderately deep, U-shaped. Shell colouration light to dark orange, with dark orange protoconch. Animal with long, cylindrical rhynchostome funnel; cephalic tentacles moderately short, cylindrical, eyes not detected. Rhynchocoel long, capacious.

\section{Remarks}

This species exhibits a very similar sculpture to that of four other Famelica species: $F$. tasmanica (Fig. 4D-F), F. pacifica (Fig. 4C), F. catharinae (Fig. 4B) and F. monoceros, from which it can be distinguished by possessing a notably higher spire. Among the high-spired Famelica species, F. turritelloides can be recognised by its strongly convex whorl profile and orange shell colour. While eyes have not been observed in studied material, it cannot be ruled out that they occur.

Famelica acus n. sp. (PSH F2)

(Figs 3A, 5C-D)

\section{Material examined}

Holotype (Fig. 5C): New Caledonia, (-22.33, 167.37), EXBODI, CP3844, 815-970 m (MNHN IM-2009-24922). COI: MW459351. 
518 Paratype (Fig. 5D): Australia, GAB, (-34.77, 130.71), IN2017_C01_207, 3389 m, 1 wet (=

519 ethanol-preserved specimen) (SAMA D49339).

521 Distribution

522 New Caledonia and GAB.

Etymology

In reference to its very elongate shell, derived from 'acus' (Latin = needle). Noun in apposition.

527

ZooBank registration http://zoobank.org/urn:Isid:zoobank.org:act:03D9ECD1-37D1-439D-9DF9-4DF189D8F801

Description. Shell ( $S L=19.1, \mathrm{SW}=3.4 \mathrm{~mm}$ ) very thin-walled, fragile, lanceolate-fusiform to turriform. Protoconch pagodiform, multispiral, of four dark orange whorls, three of which bearing a median keel, with axial pillars below the keel and no sculpture above. Teleoconch of seven evenly convex, uniformly white semitransparent whorls. Subsutural ramp indistinct on early whorls; more clearly demarcated after onset of spiral sculpture, steep, moderately wide. Sculpture of very thin cords (about 36 on last whorl) and very fine collabral growth lines. Last adult whorl convex, clearly demarcated from long, tapering siphonal canal by smooth, shallow, concave transition. Aperture elongate, one third of shell length. Outer lip thin, unsculptured, attenuated towards tip of siphonal canal in its lower portion; inner lip smooth, with no callus. Anal sinus rather shallow, U-shaped. Animal with short, broad

541 funnel (possibly contracted upon fixation); cephalic tentacles moderately short, somewhat tapering, small eyes situated at their lower portion, adjacent to base. Rhynchocoel capacious.

Remarks The very elongate, weakly sculptured shell (Fig. 5C-D) differentiates this species from most

547 of its congeners. F. bitrudis possesses a very similar, but broader and shorter shell, which lacks spiral sculpture (Barnard 1963, fig. 1b; Sysoev 1996b, figs 28-29). Remains of setae of syllid polychaetes were found in the digestive tract of the paratype specimen. The 
rhynchostome funnel in this species is most likely long as in F. turritelloides n. sp., as indicated by dense latitudinal folds in the rhynchodeum floor, suggesting it has become fixed in a retracted state.

\section{Famelica tasmanica Sysoev \& Kantor, 1987 (PSH F3)}

(Figs 4D-F)

Famelica tasmanica - Sysoev \& Kantor, p. 1256, figs 6-в

\section{Material examined}

Other material: Australia, Tasmania, Flinders CMR, (-40.473, 149.397), IN2017_V03_015, 4114-4139 m, 1 wet (AMS C.571629); Australia, NSW, off Bermagui, (-36.35, 150.91), IN2017_V03_043, 4763-4750 m, 1 wet (AMS C.519370).

\section{Remarks}

Both specimens studied here (Fig. 4E-F) are significantly larger than the holotype (Fig. 4D), this owing to difference in age.

\section{Genus Glaciotomella Criscione, Hallan, Puillandre \& Fedosov, 2020}

Type species: Glaciotomella investigator Criscione, Hallan, Puillandre \& Fedosov, 2020 by original designation

\section{Diagnosis}

Shell with cyrtoconoid spire, chalky, semitranslucent to opaque. Protoconch whorls 3 to 4 with dense, thin axial riblets and prominent median carina. Protoconch-teleoconch boundary sharp. Teleoconch of about five whitish whorls; whorl profile with weakly pronounced subsutural ramp, broadly convex below. Suture deep. Sculpture below subsutural ramp of low collabral axial ribs. Spiral sculpture of evenly distanced primary cords, slightly weaker than axial ribs, and 1-3 weaker secondary cords in intersections between primary ones. Last adult whorl globose, siphonal canal long, clearly differentiated from shortly constricted base. Aperture broadly pyriform, about half of shell length. Anal sinus moderately deep, J-shaped. Cephalic tentacles small; eyes minute. Rhynchostome and 
rhynchostomal sphincter extremely large; rhynchocoel short, rhynchostome funnel moderately developed. Radula of long, straight, cylindrical hypodermic teeth with no distinct barbs or blades.

\section{Remarks}

Glaciotomella is defined by the combination of: (a) a multispiral, axially ribbed and keeled protoconch (Fig. 3B), (b) strongly convex whorls, with cancellate sculpture (Fig. 6C-D, but also Criscione et al. 2021, fig. 3g) and (c) straight hypodermic teeth with no barbs or blade (Fig. 6). The protoconch description contained in the diagnosis (above) is based on the type species (SAMA D44120 - not figured due to erosion) and on the PSH GA (MNHN IM-200919042; Fig. 3B). Such protoconch morphology is uncommon among raphitomids and (besides Glaciotomella) is possessed only by species of Neopleurotomoides Shuto, 1971, such as the type species N. rufoapicatus (Schepman, 1913) (Schepman 1913, p. 75, pl. 29, fig. 6c; Shuto 1971p. 6, pl. 1, fig. 2), N. distincta (Bouchet \& Warén, 1980) (Bouchet and Warén 1980, p. 43, fig. 233), N. callembryon (Dautzenberg and Fischer, 1896) (Bouchet and Warén 1980, p. 43, fig. 232) and N. aembe (Figueira \& Absalão, 2012) (Figueira and Absalão 2012, p. 8, fig. 7). General shell morphology and sculpture are very similar in species of Glaciotomella (this study, Fig. 6A-C; Criscione et al. 2021, fig. 3g) and Neopleurotomoides (Fig. 6D and Bouchet and Warén 1980, figs 100-103; Figueira and Absalão 2012, figs 5-6), with species of the former differing mainly by their considerably larger shells. In addition, species of the two genera share nearly identical, unbarbed hypodermic teeth (Fig. 6 for Glaciotomella; see Bouchet and Warén 1980, fig. 45 for Neopleurotomoides). The remarkable morphological similarity between Glaciotomella and Neopleurotomoides may be an indication of a close phylogenetic relationship. However, the extent of this relationship and its resulting taxonomic implications are still to be determined, pending availability of molecular data on the type species of Neopleurotomoides.

Glaciotomella species are also similar to species of Pleurotomella s.s. (see Criscione et al. 2021 ) in possessing a shell with prominent sculpture, strongly convex whorls with an impressed suture and a long siphonal canal and a comparatively straight, awl-shaped radula. However, they differ from the latter genus in having a distinctly broader, more convex and less shouldered whorl profile. While further study is required on the radula in both genera, differences based on examinations thus far are that Glaciotomella does not possess a barb 
or blade, is very straight and relatively cylindrical, and has a comparatively small ligament, whereas Pleurotomella may possess a very small dorsal blade, is more tapering and slightly curved, and generally has a larger ligament. Furthermore, our molecular analyses (Fig. 2, S2) are in agreement with that of Criscione et al. (2021) and suggest that the two genera are in fact not closely related within Raphitomidae.

\section{Glaciotomella investigator Criscione et al., 2020 (PSH G1+G2)}

(Figs 6A-B, 9A-B)

\section{Material examined}

Holotype (Fig. 6A): Australia, New South Wales (NSW), Hunter CMR, (-32.575, 153.162), IN2017_V03_070, 2595-2474 m (AMS C571621).

Other material: Australia, GAB, $(-34.62,130.28)$, IN2015_C02_449, 2007-2067 m, (SAMA D44120).

\section{Distribution}

\section{Southern and Eastern Coast of Australia}

\section{Remarks}

This genus was previously known only for the holotype of its type species $G$. investigator, described without mention of its heavily eroded protoconch (Criscione et al. 2021, p. 25). The additional specimen studied here for the species, SAMA D44120, was collected with an intact protoconch that is described as follows: protoconch whorls three with dense, thin axial riblets and a prominent median carina; protoconch-teleoconch boundary sharp. Unfortunately, the apex was accidentally damaged while the specimen was being handled for DNA extraction and cannot be illustrated. A nearly identical protoconch is possessed by MNHN IM-2009-19042 (GA; Fig. 3B).

\section{Genus Rimosodaphnella Cossman, 1916}

Type species: Murex textilis Brocchi, 1814by subsequent designation by Cossmann (1916) 
Diagnosis

Shell elongate-fusiform, moderately thick, with high spire. Protoconch multispiral, dark orange, with diagonally cancellate sculpture. Teleoconch white to cream to pale purple; whorl profile evenly convex (with angulation) to subcylindrical or pagodiform. Suture deeply impressed. Subsutural ramp wide, concave, rather steep, sculptured by dense, raised arcuate growth lines, indicating shape of the anal sinus. Below subsutural ramp, axial sculpture of regular, opisthocline ribs, rarely absent. Spiral sculpture of rather densely set cords, overriding axials, and typically forming nodules at intersections. Last adult whorl evenly convex below subsutural ramp, clearly demarcated from straight, moderately long siphonal canal. Aperture elongate, outer lip thin, inner lip with thin callus, gently recurved toward left. Anal sinus wide, deep, u-shaped. Animal uniform cream; head broad, blunt. Cephalic tentacles tapering evenly toward blunt tip; eyes very small. Proboscis relatively long (broad and short when retracted); venom gland, convoluted; muscular bulb pearlescent, kidney-shaped to ovate. Radular teeth of hypodermic type, straight, tightly rolled, often rugose; barbs absent; adapical opening elongate; ventral blade sharp; base moderately broad; lateral process present; basal opening subcircular. Ligament moderately large, broad.

Remarks

Two main combined diagnostic features define Rimosodaphnella, namely: (a) a high-spired shell with cancellate sculpture (Brocchi 1814, p. 283, pl. 8, fig. 14; McLean and Poorman 1971, p. 111, fig. 50; Bonfitto and Morassi 2013, figs. 1A-C, G-I, P, 2A-B) and (b) straight, tightly rolled, unbarbed hypodermic teeth with a sharp dorsal blade (Fig. 10). An exhaustive comparison of the shell of Rimosodaphnella with the shell of other raphitomid genera can be found in Bonfitto and Morassi (2013). Bonfitto and Morassi (2013) critically reviewed the Recent and fossil species attributed to Rimosodaphnella, restricting this genus to its fossil type species R. textilis (Brocchi, 1814) (Fig. 7l) and to four additional Recent species: $R$. morra (Dall, 1881) (Fig. 7J, off Cuba, 822 m), R. brunneolineata Bonfitto \& Morassi, 2013 (Fig. 8A) and R. tenuipurpurata Bonfitto \& Morassi, 2013 (Fig. 8J) and (both from the Philippines, 180-250 m) as well as R. solomonensis Bonfitto \& Morassi, 2013 (Fig. 8D) (from Solomon Islands and Vanuatu, 456-551 m). Bonfitto and Morassi (2013) removed from the genus R. deroyae McLean \& Poorman 1971 (off Galapagos Islands, 200 m). However, the 
observation of the shell of the holotype (Fig. $7 \mathrm{H})$ is consistent with its inclusion in Rimosodaphnella. With the addition of the two species named herein, the total number of species of Rimosodaphnella (both fossil and Recent) is increased to eight. While generic attribution is molecularly confirmed for four out of seven Recent Rimosodaphnella species (Figs 2 and S2), genetic data is pending for the remaining three species.

Rimosodaphnella guraradara $\mathrm{n} . \mathrm{sp}$. (PSH R1)

(Figs 7A-C, 10A)

Material examined

Holotype (Fig. 7A). Australia, NSW, Jervis CMR, (-35.33, 151.26), IN2017_V03_056, 26502636 m, (AMS C.571613). COI: MN983199

Paratypes. As per holotype, 1 wet (AMS C.571684), 1 wet (AMS C.571688); Tasmania (TAS), Freycinet CMR, (-41.73, 149.12), IN2017_V03_004, 2820-2751 m, 1 wet (AMS C.519332), 1 wet (AMS C.571770); TAS/Victoria (VIC), Bass Strait, (-39.46, 149.28), IN2017_V03_022, 2760-2692 m, 1 wet (AMS C.482194).

\section{Etymology}

In reference to the long hypodermic teeth of its radula, derived from the combination of 'gurara' (Aboriginal Australian language Tharawal = long) and 'dara' (Tharawal = tooth), noun in apposition.

ZooBank registration

http://zoobank.org/urn:Isid:zoobank.org:act:3D4ED0A0-FF1E-4E76-9D5E-7CDD91062F73

Distribution

Tasman Sea.

Description. Shell elongate-fusiform, ( $\mathrm{SL}=22.8 \mathrm{~mm}, \mathrm{SW}=8.8 \mathrm{~mm})$, apex pointed but protoconch eroded. Teleoconch uniformly whitish, 5.5 whorls; whorl profile convex, with moderate angulation in earlier whorls. Subsutural ramp wide, concave, rather steep; suture deeply impressed. Sculpture of regular rounded, opisthocline ribs (about 20 on penultimate whorl) on whorl periphery, intersected by uneven flattened cords, separated by deep and 
narrow striae. Ribs more elevated on early teleoconch whorls and becoming lower, with shallower interspaces on last adult whorl. Spiral cords forming weak, horizontally elongated nodules at intersections with axial ribs. Subsutural ramp sculptured by dense, raised arcuate growth lines, indicating shape of the anal sinus. Last adult whorl evenly convex below subsutural ramp, clearly demarcated from straight, moderately long siphonal canal. Last whorl periphery with predominant spiral sculpture; axial ribs becoming obsolete toward base. Aperture elongate, approximately $40 \%$ of shell length; outer lip thin, unsculptured; inner lip whitish, with thin callus, gently recurved toward left. Anal sinus wide, deep, Ushaped. Animal uniform cream; head broad, blunt. Cephalic tentacles of medium length, broad at base, tapering evenly toward blunt tip; weak longitudinal furrow observed in right tentacle of one specimen; eyes very small. Proboscis relatively long (broad and short when retracted); venom gland of medium length, convoluted; muscular bulb pearlescent, beanshaped to ovate, of medium size. Radular tooth hypodermic, straight, tightly rolled, attaining approximately $175 \mu \mathrm{m}$ in length; barb absent; adapical opening elongate; ventral blade sharp, approximately $1 / 5$ of length of tooth; basal third of tooth somewhat rugose, in some teeth distinctly rugose throughout, in places with deep indentations; base moderately broad, rugose; lateral process present; basal opening subcircular, unrestricted. Ligament relatively large and broad.

Remarks

The shell of this species (Fig. 7A-C) can be differentiated from most congeners by the combination of larger size and convex whorl profile with weakly-defined shoulder. $R$. truvana is comparable in size and sculpture but possesses distinctly shouldered whorls. Most other congeners, particularly R. deroyae (Fig. 7H) and the PSHs RC, RD and RE (Fig. 8GI), possess fewer but more prominent sculptural elements. Finally, the PSH RA (Fig. 7G) can be differentiated from $R$. guraradara by a complete lack of axial elements in the former. The radula of $R$. guraradara is considerably longer than that of $R$. truvana based on the material 
Material examined

Holotype (Fig. 7D). Australia, TAS/VIC, Bass Strait, (-39.55, 149.55), IN2017_V03_030, 41974133 m, (AMS C.571685). COI: MN983200.

Paratypes. As per holotype, 1 wet (AMS C.519315), 1 wet (AMS C.519316), 1 wet (AMS

C.571615), 1 wet (AMS C.571686), 1 wet (AMS C.571689); TAS, Flinders CMR, (-40.47, 149.40), IN2017_V03_015, 4114-4139 m, 1 wet (AMS C.571687).

\section{Etymology}

In reference to the closest land mass to the type locality, derived from 'Truvana' (Aboriginal Australian language Palawa Kani = Cape Barren Island), name in apposition.

Zoobank registration number

http://zoobank.org/urn:Isid:zoobank.org:act:614EE2C7-1A95-4049-9179-08DA467FD60D

Distribution

Tasman Sea.

Description. Shell solid, broadly fusiform, $(\mathrm{SL}=24.5 \mathrm{~mm}, \mathrm{SW}=11.2 \mathrm{~mm})$, protoconch eroded. Teleoconch uniformly whitish, of at least six whorls. Early teleoconch whorls convex, subsequent whorls distinctly shouldered with nearly subcylindrical profile, giving spire somewhat stepped appearance. Suture impressed. Subsutural ramp concave, sculptured with fine, arcuate collabral growth lines. Sculpture of rounded, slightly opisthocline axial ribs (about 22 on penultimate and last whorl) intersected by dense, uneven cords. Axials more elevated, with deeper interstices on early teleoconch whorls and lower, densely set on last adult whorl. Spiral cords rounded, becoming somewhat nodulose at intersections with axial elements. Last adult whorl strongly convex, sculptured predominantly by spiral elements, clearly demarcated from long and slender siphonal canal. Aperture wide, elongate-pyriform, approximately half of shell length; outer lip thin, simple; inner lip whitish, with welldeveloped callus, gently twisting toward left. Anal sinus wide, moderately deep, U-shaped. Anatomy (based on holotype and paratypes AMS C.571687, C.571686, C.571689): animal uniform whitish to cream; head broad, blunt. Penis large, somewhat flattened, muscular, coiling clockwise, $1 / 4$ distal end tapering. Cephalic tentacles broad, of medium length, 
774 cylindrical, tip blunt; eyes very small. Osphradium and ctenidium large. Venom apparatus:

775 Proboscis far retracted into rhyncocoel in specimens examined; venom gland moderately

776 long, convoluted; muscular bulb large, pearlescent, kidney shaped.

777 Radular teeth of hypodermic type, straight, tightly rolled, attaining approximately $125 \mu \mathrm{m}$ in

778 length; barb absent; terminal pore elongate; ventral blade sharp, approximately $1 / 5$ of

779 length of tooth; some teeth rugose, in places with deep indentations; base moderately

780 broad, of coarse texture; lateral process present; basal opening subcircular. Ligament

781 comparatively broad and large.

782

783 Remarks

784 Rimosodaphnella truvana n. sp. can be distinguished from all other congeners by its much

785 broader and larger shell with a subcylindrical rather than convex whorl outline (Fig. 7D-F). It

786 differs from the shell of $R$. guraradara (Fig. 7A-C) by its far more angular shoulder at the

787 whorl periphery, the length of its aperture which is approximately equal to the length of the

788 spire (compared to the relatively shorter aperture in the former), and its more pronounced

789 cancellate sculpture. The radula of $R$. truvana is shorter than that of $R$. guraradara. 
Discussion

The five-gene phylogeny of Criscione et al. (2020) established the phylogenetic framework upon which the new genus Glaciotomella was recognised and described, and it is shown herein that there is strong support in both $\mathrm{BI}$ and $\mathrm{ML}$ analyses for its monophyly, as is the case for Famelica and Rimosodaphnella (Figs 2, S2). The level of genetic distinctiveness reported for cox1 sequences of the three genera (Tables 1,2 ) was generally comparable with those reported for the other deep-sea raphitomid genera (Hallan et al. 2021; Criscione et al., in press) at the intra-specific level, but overall higher (up to more than three times; e.g. average $4.1 \%$ in Theta vs. $14.2 \%$ in Glaciotomella) at the inter-specific level. It remains unclear whether this is a reflection of a comparatively reduced species sampling (most species of these genera have low abundance) or indication of a higher diversification rate in these lineages when compared with other raphitomid genus-level lineages. Other than being supported by molecular evidence, the integrity of the genera studied herein is also corroborated by morpho-anatomical features diagnostic for each genus. Among those features, the sculpture of the protoconch and the radula were particularly conserved among congeneric species and therefore represented solid diagnostic genus-level characters.

Rimosodaphnella possessed a multispiral larval shell, with protoconch II exhibiting a diagonally cancellate sculpture (Fig. 3C). This configuration is the most commonly recorded in Raphitomidae, where it may display a range of variations. Conversely, protoconchs with a keel and axial 'pillars', such as those observed here for Famelica and Glaciotomella (Fig. 3AB) are considered a departure from the prevailing raphitomid pattern (Bouchet et al. 2011). Among deep-sea raphitomid genera, keeled protoconchs are shared by Famelica, Aliceia, Neopleurotomoides and Glaciotomella, which can be separated into pairs by the two former genera having no axial elements above the keel, as opposed to the two latter ones where axial elements persist above the keel. This, and other obvious morpho-anatomical affinities, exhibited in pairs by these genera (see above Remarks to genera), coupled with the close phylogenetic relationship between Famelica and Glaciotomella (this study, Figs 2, S2; Criscione et al. 2021, fig. 2), might suggest that all deep-sea raphitomid genera with keeled protoconchs are part of the same lineage (clade A of fig. 2 of Criscione et al. 2021), although this requires testing through molecular data. Nevertheless, owing to the presence in that lineage of at least one genus with a typical diagonally cancellate protoconch 
822 (Rimosodaphnella: this study, Figs 2, S1; Criscione et al. 2021, fig. 2), it is unlikely that a

823 'keeled-pillared' protoconch is the plesiomorphic state for this lineage (Criscione et al. 824 2021).

825 Three main types of radular morphology have been reported for Australian deep-sea raphitomid genera (Criscione et al. 2021): (1) double-barbed, (2) awl-shaped with dorsal blade and (3) awl-shaped with no distinct blade. The latter two were recorded for two genera in this study: (2) in Rimosodaphnella (Fig. 10) and (3) in Glaciotomella (Fig. 9). The hypodermic teeth lacking barbs or blades, or reduced in size are commonly found in raphitomids, and are thought to be a result of secondary simplification of morphology (Kantor and Taylor 2002, see also below)(Kantor \& Taylor 2002, also see discussion below). Unfortunately, diagnostic value of simplified morphology is questionable as it is virtually impossible to extract a phylogenetic signal associated with loss of a structure and to ascertain, whether loss of certain feature has happened once or several times in the evolution.

None of the species of Famelica studied here possess a radula or a venom apparatus, in agreement with that reported by Criscione et al. (2021) for the genus. As hypodermic teeth as well as a well-developed intraembolic proboscis and venom gland are plesiomorphic in Raphitomidae (Kantor and Sysoev 1989; Bouchet et al. 2011), the lack or reduction of these structures in some lineages has been interpreted as a derived state, which has occurred independently in multiple unrelated deep-sea lineages (Kantor and Taylor 2002; Criscione et al. 2021). The loss of such structures (involved in predation by stabbing and injecting venom) has in some studies been associated with adaptation to alternative feeding strategies (Kantor and Sysoev 1989; Taylor et al. 1993; Kantor and Taylor 2002). In some raphitomid groups, the loss of radula and venom apparatus has been accompanied by substantial anatomical modifications, such as the development of a prominent rhynchodeal introvert (e.g. some Raphitoma spp.), the expansion of the cavity between rhynchodeum and body walls (e.g. Abyssobela Kantor \& Sysoev, 1986 and Teretiopsis Kantor \& Sysoev, 1989) or the evolution of accessory rhynchodeal organs (e.g. Tritonoturris subrissoides (Hervier, 1897); Fedosov 2007). No obvious anatomical rearrangements have occurred in some other groups (e.g. Taranis Jeffreys, 1870). The well-developed rhynchodeal introvert was also found to be a common feature in Terebridae, another lineage of Conoidea remarkable for tendency toward complete loss of the venom apparatus (Taylor 1990; Taylor 
et al. 1993; Castelin et al. 2012). Furthermore, terebrid species with a well-developed proboscis and hypodermic radulae appeared to have smaller introverts compared to those with reduced or lacking radula and/or proboscis (Taylor 1990). This observation had corroborated earlier observation on the feeding of terebrids, which demonstrated that the rhynchodeal introvert plays a primary role in feeding for some terebrids (Miller 1975). In Raphitomidae it was also showed that a well-developed introvert can occur in taxa possessing a prominent venom apparatus and radula: Hemilienardia, Austrobela and Pueridaphne (Kantor and Taylor 2002; Criscione et al. 2021). One could hypothesize that development of a functional rhynchodeal introvert is a prerequisite to simplification of the organs related to envenomation (which has occurred in most living Raphitomidae), often leading to their complete reduction. It is possible that initially, the role of the introvert was limited to retention of prey during envenomation, as for cone-snails of the subgenus Conus (Gastridium). Conids of this group first engulf fish-preys into an enormous rhynchostome funnel, and then stab them with a radular harpoon (Olivera et al. 2015) Species of Conus (Gastridium) are remarkable for their simplified radular teeth, lacking elaborated barbs and serrations, that are structures that keep prey 'hooked' preventing its escape. Indeed, once prey is enclosed in a rhynchocoel, it cannot escape, and as the retention of prey is taken over by rhynchostome funnel, elaborated radular weaponry becomes unnecessary, and undergoes reduction. The widespread morphological simplification of the hypodermic teeth in Raphitomidae can possibly be explained by the same causal link (i.e. by partial transfer of their functions to the rhynchodeal introvert). Progressively, the introvert might enable alternative feeding mechanisms, which do not require envenomation (similar to the mechanisms observed in Terebridae) and which eventually led to the complete loss of radula, venom gland and proboscis. Some occasional prey findings in radula-less raphitomids (e.g. polychaete setae identified as belonging to a member of the family Syllidae, recovered from Famelica acus n. sp. SAMA D49339) suggest that these species retain a predatory lifestyle.

Shells are heterogeneous for most species of all three genera, but generally exhibit similar gross morphology, with very few exceptions. The overall strongly elongate shell shape of Famelica (Fig. 4-5), the fusiform shell with strongly convex whorls of Glaciotomella (Fig. 6) and the cancellate teleoconch sculpture of Rimosodaphnella (Fig. 7-8) are the main recognisable characters in their respective composite taxa. However, while most congeneric 
species are similar in shell morphology [e.g. F. tasmanica (Fig. 4D-F), F. acus (Fig. 5D-E) and F. turritelloides (Fig. 4A), R. guraradara (Fig. 7A-C) and R. truvana (Fig. 7D-F) or $R$. brunneolineata (Fig. 8A-C) and R. solomonensis (Fig. 8D-F)], other species or PSHs [e.g. F. polyacantha (Fig. 5F-G) or Rimosodaphnella RA (Fig. 7G)] exhibit shell features that are somewhat divergent from those shared by their congeners. Some species of Rimosodaphnella and Glaciotomella studied here have much larger shells than others. Although the small sample size did not allow thorough statistical testing, the size of their shells (and bodies) appears to be positively correlated with depth, with species from the lower bathyal (i.e. R. guraradara and R. truvana for the former genus and G. investigator for the latter) larger than species (or PSHs) of shallower waters (i.e. R. brunneolineata and Glaciotomella GA for each genus respectively). A size-depth clinal pattern is well-known for bathyal neogastropods (Rex and Etter 1998; Harasewych and Kantor 2004; McClain et al. 2005) and for turriform conoideans in particular ('turrids' in Rex et al. 1999; McClain and Rex 2001) and has been interpreted as an adaptive response to an environmental gradient in the deep sea. The increase in maximum size attained with depth would provide these snails with increasing metabolic rates and competitive advantages as food resources diminish (Rex and Etter 1998; Rex et al. 1999). For instance, as their polychaete prey becomes scarcer with depth (Thistle et al. 1985), larger raphitomids may benefit from increased mobility as well as ability to feed on a wider range of prey sizes (Levinton 1982, 1987). As is often the case for deep-sea studies, it is difficult to establish the extent to which inevitably limited observations reflect such adaptive mechanisms, and to which they are confounded by sampling biases (see Criscione et al. 2021).

Biogeographic and bathymetric patterns

Most species treated herein occur within an area corresponding approximately to the South Australia marine realm of Costello et al. (2017). Unsurprisingly, the records are concentrated in the areas of sampling: a relatively restricted portion of the GAB and on a section of the temperate eastern Australian coast between south-eastern Tasmania and Moreton Bay (Fig. 1). Samples included in this study that were collected outside this region tend to cluster around the areas targeted during MNHN-led voyages in the tropical IndoPacific and Pacific (Table S1). 
917 Of the three genera studied here (restricted to the sequenced samples), one (Glaciotomella) seems to be relatively restricted, recorded only in Australia and Melanesia (Fig. 1A) whereas the other two have ranges that from South Australia extend respectively to the Central Pacific (Famelica, Fig 1A) and to the Central and Eastern Pacific (Rimosodaphnella, Fig. 1B). When Famelica is regarded in its entirety (i.e. including all species herein attributed to it, irrespective of the availability of molecular data for them - see Remarks under this genus), it displays a much broader, transoceanic range, encompassing all of the world's Oceans. Geographic ranges of comparable size, purportedly stretching over two or more Oceans, have been reported for other raphitomid genera present in Australia, such as Austrobela and Theta (Criscione et al., in press) as well as Pagodibela (Hallan et al. 2021). If confirmed by molecular data, a hypothetical Glaciotomella + Neopleurotomoides genus-level group (see above), including species from three different Oceans, would also feature a similarly broad range. When Rimosodaphnella is regarded in its entirety (i.e. including species whose attribution is pending molecular testing), it exhibits a prevalent South Pacific distribution. However, further sampling outside this area (such as the Atlantic, where $R$. morra is found) may reveal the presence of further species. Among the species reported here for Australia, none occur outside the two realms encompassing Australian waters (Fig. 1). However, future deep-sea sampling may reveal records beyond these realms, particularly for species occurring further north, such as F. acus or F. turritelloides n. spp. Species of other deep-sea raphitomid genera, recorded for the Tropical Australia \& Coral Sea realm (\#16 of Costello et al. 2017), commonly have ranges extending into neighbouring tropical realms [Hallan et al. (2021) for Pagodibela baruna (Sysoev, 1997); Criscione et al., in press for Austrobela procera (Sysoev \& Bouchet, 2001) and Spergo fusiformis (Habe, 1962)]. The comparatively wide geographic distributions of F. acus and G. investigator are not entirely unexpected given the mounting evidence of wide distributions in some species of other deep-sea raphitomid genera, such as Austrobela, Spergo and Theta (Criscione et al., in press) as well as Gladiobela and Pagodibela (Hallan et al. 2021). As neighbouring regions with comparable environmental conditions remain virtually unexplored, it is plausible that disjunct distributions, like that observed for $F$. acus and $G$. investigator (Fig. 1A), are the result of sampling bias, rather than a reflection of any underlying biological process. Low mean cox1 genetic distance between two populations, when compared with the range of distances calculated within one of the populations of the 
raphitomid Gladiobela angulata Criscione, Hallan, Puillandre \& Fedosov, 2020 has been interpreted as indication of high genetic connectivity (Hallan et al. 2021). In order to perform similar comparisons for F. acus and G. investigator, more than one sequence from each of the two disjunct populations would be necessary. In addition, due to the aforementioned sampling bias, it remains unclear whether genetic connectivity in these species is realised through a stepping-stone process, involving additional geographically intervening populations, or through long-range dispersal of the planktotrophic larva (or both).

Rimosodaphnella guraradara and $R$. truvana are present in sympatry off the coast of East Tasmania (Fig. 1B), where there is no overlap in their bathymetric ranges, with a gap of more than $1000 \mathrm{~m}$ (Fig. 11), despite some sampling coverage within this gap at corresponding areas. It has been suggested that partitioning into separate bathymetric niches is the driver of speciation of sister species of some other Australian deep-sea raphitomid genera, such as Gladiobela (Hallan et al. 2021) and Austrobela (Criscione et al., in press), albeit the ecological factors involved remain unknown. As $R$. guraradara and $R$. truvana are not recovered as sister taxa based on our results, speciation via bathymetric partitioning appears unlikely; rather, a scenario of a secondary contact between the two species appears more plausible.

Due to the limited material of $F$. turritelloides, we cannot infer much about its biogeography. While it cannot be ruled out that its rarity may be an artefact of sampling, it is possible that this species may indeed be relatively rare, as the regions in which it has been collected are comparatively well-sampled (Maclntosh et al. 2018; O'Hara et al. 2020) and have revealed the presence of a diverse raphitomid fauna (Criscione et al., 2020). For species of other raphitomid genera from the same regions, such as Gladiobela (Hallan et al. 2021), Theta and Austrotheta (Criscione et al., in press), scarce records have been interpreted as evidence of their intrinsic rarity. Conversely, some Rimosodaphnella species studied here, notably $R$. guraradara and $R$. truvana, can be considered relatively common, as observed for most species of Austrobela (Criscione et al., in press) and some of Gladiobela (Hallan et al. 2021). Estimates of bathymetric ranges of deep-sea turriform conoideans genera have traditionally relied on morphology-based genus attribution (Bouchet 1990; Kantor et al. 2016). For raphitomid genera, Criscione et al. (2021) provided the first available depth range size, based on Australian species whose generic attribution was confirmed by molecular data. By 
981 complementing molecular data on further species from beyond Australia, this and other

982 studies suggest range size expansions for a number of these genera. Among these expanded 983 depth ranges, those of Spergo Dall, 1895 (4432 m; Criscione et al., in press), Famelica (4352 984 m; this study), Gladiobela Criscione, Hallan, Puillandre and Fedosov, 2020 (4276 m; (Hallan 985 et al. 2021) and Rimosodaphnella (3874 m; this study) are the widest four reported for the 986 family to date. The bathymetric range of F. acus (at least $2574 \mathrm{~m}$; Fig. 11) constitutes one of 987 the widest ever reported for a molecularly confirmed conoidean species, second only to that 988 of Gladiobela acris Hallan, Criscione, Fedosov and Puillandre, 2021 (Hallan et al. 2021). Due 989 to the scarcity of material for most other species studied here, little inference can be made 990 with regards to their bathymetric zonation. 
Conflict of interest

The authors declare no conflicts of interest.

Acknowledgments

This work has been made possible through financial support from the Australian

Government (ABRS grant RF217-57, principal investigator FC). The participation of AF was also supported by the Russian Science Foundation (grant 19-74-10020). The participation of NP was also supported by the European Research Council (ERC) under the European Union's Horizon 2020 research and innovation programme (grant agreement No. 865101). Voyages in the GAB were part of: (a) the GAB Research Program [GABRP - a collaboration between BP, CSIRO, the South Australian Research and Development Institute (SARDI), the University of Adelaide and Flinders University] and (b) the GAB Deepwater Marine Program (GABDMP - a CSIRO led research program sponsored by Chevron Australia]. Funding for the 'Eastern Abyss' voyage (IN2017_V03) was provided by the Marine Biodiversity Hub (MBH), supported through the Australian Government's National Environmental Science Program (NESP). The authors wish to thank the CSIRO MNF for its support in the form of sea time onboard, support personnel, scientific equipment and data management. We also thank the scientific staff and crew who participated in all voyages generating the samples studied herein. The MNHN samples used in this study originates from shore-based expeditions (PANGLAO 2004, PAPUA NIUGINI; PI Philippe Bouchet) and deep-sea cruises (AURORA 2007, BIOPAPUA, BOA 1, EXBODI, KANACONO, KAVIENG 2014, MAINBAZA, PANGLAO 2005, SALOMON 2, SALOMON BOA 3, TARASOC, ZHONGSHA 2015; PIs Philippe Bouchet, Tin-Yam Chan, Laure Corbari, Nicolas Puillandre, Sarah Samadi, Wei-Jen Chen, Bertrand Richer de Forges) conducted by MNHN, Pro-Natura International (PNI) and Institut de Recherche pour le Développement as part of the Our Planet Reviewed and the Tropical Deep-Sea Benthos programs. Funders and sponsors included a bilateral cooperation research funding from the Taiwan Ministry of Science and Technology (MOST 102-2923-B-002-001-MY3, PI Wei-Jen Chen) and the French National Research Agency (ANR 12-ISV7-0005-01, PI Sarah Samadi), the Total Foundation, Prince Albert II of Monaco Foundation, Stavros Niarchos Foundation, and Richard Lounsbery Foundation. One sample was collected during the INSPIRE cruise (Chile) onboard R/V Melville (SCRIPPS institutions). All expeditions operated under the regulations then in force in the countries in question and satisfy the conditions set by the 
1023 Nagoya Protocol for access to genetic resources (expeditions.mnhn.fr). We would like to 1024 express our gratitude to Mandy Reid, Alison Miller and Jennifer Caiza (AMS) for assistance 1025 with registration and databasing of material, to Virginie Héros, Philippe Maestrati and 1026 Barbara Buge (MNHN) for the sample preparation and databasing and to Andrea Crowther 1027 (SAMA, Adelaide. Thanks are also due to Sue Lindsay and Chao Shen (Macquarie University, 1028 Sydney) for facilitating SEM work. We are indebted to several people providing photos of 1029 types and other relevant specimens: Adam Baldinger and Alana Rivera (MCZ, Cambridge, 1030 USA), Antonio Bonfitto (Bologna University, Italy), Jeroen Goud and Bram van der Bijl 1031 (NMNL, Leiden), Kazunori Hasegawa (NSMT, Tokyo, Japan), Lindsey Groves (LACM, Los 1032 Angeles), Peter Stahlschmidt (Universität Koblenz-Landau, Koblenz, Germany), Ellen Strong 1033 (NMNH, Washington), Alexander Sysoev (ZMMU, Moscow), Giorgio Teruzzi and Anna 1034 Alessandrello (MSNMi, Milan). 
1035

1036

1037

1038

1039

1040

1041

1042

1043

1044

1045

1046

1047

1048

1049

1050

1051

1052

1053

1054

1055

1056

1057

1058

1059

1060

1061

1062

1063

1064

1065

1066

References

Barnard, K.H. (1963) Deep sea Mollusca from West of Cape Point, South Africa. Annals of the South African Museum 46, 407-453.

Bonfitto, A., and Morassi, M. (2013) New Indo-Pacific species of Rimosodaphnella Cossmann, 1916 (Gastropoda: Conoidea): a genus of probable Tethyan origin. Molluscan Research 33, 230-236.

Bouchet, P. (1990) Turrid genera and mode of development: The use and abuse of protoconch morphology. Malacologia 32, 69-77.

Bouchet, P., Heros, V., Lozouet, P., and Maestrati, P. (2008) 'A quarter - century of deep-sea malacological exploration in the South and West Pacific: where do we stand? How far to go?' $9-40$

Bouchet, P., and Kantor, Y.I. (2004) New Caledonia: The major centre of biodiversity for volutomitrid molluscs (Mollusca: Neogastropoda: Volutomitridae). Systematics and Biodiversity 1(4), 467-502.

Bouchet, P., Kantor, Y.I., Sysoev, A.V., and Puillandre, N. (2011) A new operational classification of the Conoidea (Gastropoda). Journal of Molluscan Studies 77(3), 273308.

Bouchet, P., Lozouet, P., and Sysoev, A.V. (2009) An inordinate fondness for turrids. DeepSea Research Part II Topical Studies in Oceanography 56(19-20), 1724-1731.

Bouchet, P., and Sysoev, A.V. (1997) Revision of the Recent species of Buccinaria (Gastropoda: Conoidea), a genus of deep-water turrids of Tethyan origin. Venus (Tokyo) 56(2), 93-119.

Bouchet, P., and Sysoev, A.V. (2001) Typhlosyrinx-like tropical deep-water turriform gastropods (Mollusca, Gastropoda, Conoidea). Journal of Natural History 35(11), 1693-1715.

Bouchet, P., and Warén, A. (1980) Revision of the north east Atlantic bathyal and abyssal Turridae (Mollusca, Gastropoda). Journal of Molluscan Studies Supplement 8, 1-119.

Brocchi, G. (1814) 'Conchiologia fossile subapennina, con osservazioni geologiche sugli Apennini e sul suolo adiacente.' (Stamperia reale: Milano)

Castelin, M., Puillandre, N., Kantor, Y., Modica, M.V., Terryn, Y., Cruaud, C., Bouchet, P., and Holford, M. (2012) Macroevolution of venom apparatus innovations in auger snails 
(Gastropoda; Conoidea; Terebridae). Molecular phylogenetics and evolution 64, 21 44.

Cossmann, M. (1916) 'Essais de paléoconchologie comparée.' (Chez l'auteur, [a la Société d'éditions et autres: Paris)

Costello, M.J., Tsai, P., Wong, P.S., Cheung, A.K.L., Basher, Z., and Chaudhary, C. (2017) Marine biogeographic realms and species endemicity. Nature Communications 8(1), 1057.

Criscione, F., Hallan, A., Puillandre, N., and Fedosov, A. (2021) Where the snails have no name: a molecular phylogeny of Raphitomidae (Neogastropoda: Conoidea) uncovers vast unexplored diversity in the deep seas of temperate southern and eastern Australia. Zoological Journal of the Linnean Society 191(4), 961-1000.

Criscione, F., Hallan, A., Fedosov, A., and Puillandre, N. Deep Downunder: Integrative taxonomy of Austrobela, Spergo, Theta and Austrotheta (Conoidea: Raphitomidae) from the deep sea of Australia. Journal of Zoological Systematics and Evolutionary Research. In press.

Dall, W.H. (1881) Reports on the results of dredging, under the supervision of Alexander Agassiz, in the Gulf of Mexico and in the Caribbean Sea (1877-78), by the United States Coast Survey Steamer "Blake", Lieutenant-Commander C.D. Sigsbee, U.S.N., and Commander J.R. Bartlett, U.S.N., commanding. XV. Preliminary report on the Mollusca. Bulletin of the Museum of Comparative Zoölogy at Harvard College 9(2), 33-144.

Dall, W.H. (1889) Reports on the results of dredgings, under the supervision of Alexander Agassiz, in the Gulf of Mexico (1877-78) and in the Caribbean Sea (1879-80), by the U. S. Coast Survey Steamer 'Blake'. XXIX-Report on the Mollusca. Part II. Gastropoda and Scaphopoda. Bulletin of the Museum of Comparative Zoology at Harvard College $18,1-492$.

Dautzenberg, P., and Fischer, H. (1896) Campagnes scientifiques de S. A. le Prince Albert ler de Monaco. Dragages effectues par l'Hirondelle et par la Princesse Alice, 18881895... I-Mollusques, Gasteropodes including Polyplacophora. Memoires de la Societe Zoologique de France ix, pp. 395-498. 
Dautzenberg, P., and Fischer, H. (1897) Campagnes scientifiques de S. A. le Prince Albert ler de Monaco. Dragages effectues par l'Hirondelle et par la Princesse-Alice, 1888-1896. Memoires de la Societe Zoologique de France x, pp. 139-234.

Dayrat, B. (2005) Towards integrative taxonomy. Biological Journal of the Linnean Society 85(3), 407-415.

Fassio, G., Russini, V., Pusateri, F., Giannuzzi-Savelli, R., Høisæter, T., Puillandre, N., Modica, M.V., and Oliverio, M. (2019) An assessment of Raphitoma and allied genera (Neogastropoda: Raphitomidae). Journal of Molluscan Studies.

Fedosov, A.E. (2007) Anatomy of accessory rhynchodeal organs of Veprecula vepratica and Tritonoturris subrissoides: new types of foregut morphology in Raphitominae (Conoidea). Ruthenica 17(1-2), 33-41.

Figueira, R.M.A., and Absalão, R.S. (2012) Deep-water Raphitomidae (Mollusca, Gastropoda, Conoidea) from the Campos Basin, southeast Brazil. Zootaxa 3527, 1-27.

Folmer, O., Black, M., Hoeh, W., Lutz, R., and Vrijenhoek, R. (1994) DNA primers for amplification of mitochondrial cytochrome c oxidase subunit I from diverse metazoan invertebrates. Molecular Marine Biology and Biotechnology 3(5), 294-299.

Hallan, A., Criscione, F., Fedosov, A., and Puillandre, N. (2021) Few and far apart: integrative taxonomy of Australian species of Gladiobela and Pagodibela (Conoidea : Raphitomidae) reveals patterns of wide distributions and low abundance. Invertebrate Systematics 35(2), 181-202.

Harasewych, M., and Kantor, Y. (2004) The deep-sea Buccinoidea (Gastropoda: Neogastropoda) of the Scotia Sea and adjacent abyssal plains and trenches. Nautilus $118,1-42$.

Hoang, D.T., Chernomor, O., von Haeseler, A., Minh, B.Q., and Vinh, L.S. (2017) UFBoot2: Improving the Ultrafast Bootstrap Approximation. Molecular Biology and Evolution 35(2), 518-522.

Horton, T., Kroh, A., Ahyong, S., Bailly, N., Boyko, C.B., Brandão, S.N., Costello, M.J., Gofas, S., Hernandez, F., Holovachov, O., Mees, J., Paulay, G., Rosenberg, G., Decock, W., Dekeyzer, S., Lanssens, T., Vandepitte, L., Vanhoorne, B., Verfaille, K., Adlard, R., Adriaens, P., Agatha, S., Ahn, K.J., Akkari, N., Alvarez, B., Anderson, G., Angel, M.V., Arango, C., Artois, T., Atkinson, S., Bank, R., Barber, A., Barbosa, J.P., Bartsch, I., Bellan-Santini, D., Bernot, J., Berta, A., Bezerra, T.N., Bieler, R., Blanco, S., Blasco- 
Costa, I., Blazewicz, M., Bock, P., Böttger-Schnack, R., Bouchet, P., Boury-Esnault, N., Boxshall, G., Bray, R., Breure, B., Bruce, N.L., Cairns, S., Cárdenas, P., Carstens, E., Chan, B.K., Chan, T.Y., Cheng, L., Churchill, M., Coleman, C.O., Collins, A.G., Corbari, L., Cordeiro, R., Cornils, A., Coste, M., Crandall, K.A., Cremonte, F., Cribb, T., Cutmore, S., Dahdouh-Guebas, F., Daly, M., Daneliya, M., Dauvin, J.C., Davie, P., De Broyer, C., De Grave, S., de Mazancourt, V., de Voogd, N.J., Decker, P., Decraemer, W., Defaye, D., d'Hondt, J.L., Dohrmann, M., Dolan, J., Domning, D., Downey, R., Drapun, I., Ector, L., Eisendle-Flöckner, U., Eitel, M., Encarnação, S.C.d., Enghoff, H., Epler, J., Ewers-Saucedo, C., Faber, M., Feist, S., Figueroa, D., Finn, J., Fišer, C., Fordyce, E., Foster, W., Frank, J.H., Fransen, C., Furuya, H., Galea, H., Garcia-Alvarez, O., Garic, R., Gasca, R., Gaviria-Melo, S., Gerken, S., Gheerardyn, H., Gibson, D., Gibson, R., Gil, J., Gittenberger, A., Glasby, C., Glover, A., Gómez-Noguera, S.E., González-Solís, D., Gordon, D., Grabowski, M., Gravili, C., Guerra-García, J.M., Guidetti, R., Guiry, M.D., Hadfield, K.A., Hajdu, E., Hallermann, J., Hayward, B.W., Hendrycks, E., Herbert, D., Herrera Bachiller, A., Ho, J.s., Hodda, M., Høeg, J., Hoeksema, B., Hooper, J.N., Houart, R., Hughes, L., Hyžný, M., Iniesta, L.F.M., Iseto, T., Ivanenko, S., Iwataki, M., Janssen, R., Jarms, G., Jaume, D., Jazdzewski, K., Jóźwiak, P., Kabat, A., Kantor, Y., Karanovic, I., Karthick, B., Kim, Y.H., King, R., Kirk, P.M., Klautau, M., Kociolek, J.P., Köhler, F., Kolb, J., Kotov, A., Kremenetskaia, A., Kristensen, R.M., Kulikovskiy, M., Kullander, S., Lambert, G., Lazarus, D., Le Coze, F., LeCroy, S., Leduc, D., Lefkowitz, E.J., Lemaitre, R., Liu, Y., Lörz, A.N., Lowry, J., Ludwig, T., Lundholm, N., Macpherson, E., Madin, L., Mah, C., Mamo, B., Mamos, T., Manconi, R., Mapstone, G., Marek, P.E., Marshall, B., Marshall, D.J., Martin, P., Mast, R., McFadden, C., McInnes, S.J., Meidla, T., Meland, K., Merrin, K.L., Mesibov, R., Messing, C., Miljutin, D., Mills, C., Moestrup, Ø., Mokievsky, V., Molodtsova, T., Monniot, F., Mooi, R., Morandini, A.C., Moreira da Rocha, R., Moretzsohn, F., Mortelmans, J., Mortimer, J., Musco, L., Neubauer, T.A., Neubert, E., Neuhaus, B., Ng, P., Nguyen, A.D., Nielsen, C., Nishikawa, T., Norenburg, J., O'Hara, T., Opresko, D., Osawa, M., Ota, Y., Páll-Gergely, B., Patterson, D., Paxton, H., Peña Santiago, R., Perrier, V., Perrin, W., Petrescu, I., Picton, B., Pilger, J.F., Pisera, A.B., Polhemus, D., Poore, G.C., Potapova, M., Pugh, P., Read, G., Reich, M., Reimer, J.D., Reip, H., Reuscher, M., Reynolds, J.W., Richling, I., Rimet, F., Ríos, P., Rius, M., Rogers, D.C., 
1161

1162

1163

1164

1165

1166

1167

1168

1169

1170

1171

1172

1173

1174

1175

1176

1177

1178

1179

1180

1181

1182

1183

1184

1185

1186

1187

1188

1189

1190

1191

Rützler, K., Sabbe, K., Saiz-Salinas, J., Sala, S., Santos, S., Sar, E., Sartori, A.F., Satoh, A., Saucède, T., Schatz, H., Schierwater, B., Schmidt-Rhaesa, A., Schneider, S., Schönberg, C., Schuchert, P., Senna, A.R., Serejo, C., Shaik, S., Shamsi, S., Sharma, J., Shear, W.A., Shenkar, N., Shinn, A., Short, M., Sicinski, J., Sierwald, P., Simmons, E., Sinniger, F., Sivell, D., Sket, B., Smit, H., Smit, N., Smol, N., Souza-Filho, J.F., Spelda, J., Sterrer, W., Stienen, E., Stoev, P., Stöhr, S., Strand, M., Suárez-Morales, E., Summers, M., Suppan, L., Suttle, C., Swalla, B.J., Taiti, S., Tanaka, M., Tandberg, A.H., Tang, D., Tasker, M., Taylor, J., Taylor, J., Tchesunov, A., ten Hove, H., ter Poorten, J.J., Thomas, J.D., Thuesen, E.V., Thurston, M., Thuy, B., Timi, J.T., Timm, T., Todaro, A., Turon, X., Tyler, S., Uetz, P., Uribe-Palomino, J., Utevsky, S., Vacelet, J., Vachard, D., Vader, W., Väinölä, R., Van de Vijver, B., van der Meij, S.E., van Haaren, T., van Soest, R.W., Vanreusel, A., Venekey, V., Vinarski, M., Vonk, R., Vos, C., Walker-Smith, G., Walter, T.C., Watling, L., Wayland, M., Wesener, T., Wetzel, C.E., Whipps, C., White, K., Wieneke, U., Williams, D.M., Williams, G., Wilson, R., Witkowski, A., Witkowski, J., Wyatt, N., Wylezich, C., Xu, K., Zanol, J., Zeidler, W., and Zhao, Z. (2019) World Register of Marine Species (WoRMS). In '.' (WoRMS Editorial Board)

Kalyaanamoorthy, S., Minh, B.Q., Wong, T.K.F., von Haeseler, A., and Jermiin, L.S. (2017) ModelFinder: fast model selection for accurate phylogenetic estimates. Nature Methods 14(6), 587-589.

Kantor, Y.I., Harasewych, M.G., and Puillandre, N. (2016) A critical review of Antarctic Conoidea (Neogastropoda). Molluscan Research 36(3), 153-206.

Kantor, Y.I., Puillandre, N., Olivera, B.M., and Bouchet, P. (2008) Morphological proxies for taxonomic decision in turrids (Mollusca, Neogastropoda): a test of the value of shell and radula characters using molecular data. Zoological Science (Tokyo) 25(11), 11561170.

Kantor, Y.I., Strong, E.E., and Puillandre, N. (2012) A new lineage of Conoidea (Gastropoda: Neogastropoda) revealed by morphological and molecular data. Journal of Molluscan Studies 78, 246-255.

Kantor, Y.I., and Sysoev, A.V. (1989) The morphology of toxoglossan gastropods lacking a radula, with a description of new species and genus of Turridae. Journal of Molluscan Studies 55, 537-549. 
Kantor, Y.I., and Taylor, J.D. (2002) Foregut anatomy and relationships of raphitomine gastropods (Gastropoda: Conoidea: Raphitominae). Bollettino Malacologico 38, 83110.

Kimura, M. (1980) A simple method for estimating evolutionary rates of base substitutions through comparative studies of nucleotide sequences. Journal of Molecular Evolution 16(2), 111-120.

Kumar, S., Stecher, G., and Tamura, K. (2016) MEGA7: Molecular Evolutionary Genetics Analysis Version 7.0 for Bigger Datasets. Mol Biol Evol 33(7), 1870-4. [In eng]

Levinton, J.S. (1982) The Body Size-Prey Size Hypothesis: The Adequacy of Body Size as a Vehicle for Character Displacement. Ecology 63(3), 869-872.

Levinton, J.S. (1987) The Body Size-Prey Size Hypothesis and Hydrobia. Ecology 68(1), 229231.

Maclntosh, H., Althaus, F., Williams, A., Tanner, J.E., Alderslade, P., Ahyong, S.T., Bax, N., Criscione, F., Crowther, A.L., Farrelly, C.A., Finn, J.K., Goudie, L., Gowlett-Holmes, K., Hosie, A.M., Kupriyanova, E., Mah, C., McCallum, A.W., Merrin, K.L., Miskelly, A., Mitchell, M.L., Molodtsova, T., Murray, A., O’Hara, T.D., O'Loughlin, P.M., Paxton, H., Reid, A.L., Sorokin, S.J., Staples, D., Walker-Smith, G., Whitfield, E., and Wilson, R.S. (2018) Invertebrate diversity in the deep Great Australian Bight (200-5000 m). Marine Biodiversity Records 11(1), 23.

McClain, C., and Rex, M. (2001) The relationship between dissolved oxygen concentration and maximum size in deep-sea turrid gastropods: an application of quantile regression. Marine Biology 139(4), 681-685.

McClain, C., Rex, M., and Jabbour, R. (2005) Deconstructing Bathymetric Patterns of Body Size in Deep-Sea Gastropods. Marine Ecology-progress Series - MAR ECOL-PROGR SER 297, 181-187.

McLean, J.H., and Poorman, L.H. (1971) New species of Tropical Eastern Pacific Turridae. The veliger. 14, 89-113.

Miller, B.A. (1975) The biology of Terebra gouldi Deshayes, 1859, and a discussion of life history similarities among other terebrids of similar proboscis type. Pacific Science 29, 227-241.

Minh, B.Q., Schmidt, H.A., Chernomor, O., Schrempf, D., Woodhams, M.D., von Haeseler, A., and Lanfear, R. (2020) IQ-TREE 2: New Models and Efficient Methods for 
Phylogenetic Inference in the Genomic Era. Molecular Biology and Evolution 37(5), 1530-1534.

Morassi, M., and Bonfitto, A. (2006) Cryptodaphne kilburni, a new species of bathyal turrid (Gastropoda: Prosobranchia) from the Gulf of Aden (Northwestern Indian Ocean). Veliger 48(3), 230-233.

Morassi, M., and Bonfitto, A. (2015) New Indo-Pacific species of the genus Teretia Norman, 1888 (Gastropoda: Raphitomidae). Zootaxa 3911(4), 560-570.

O'Hara, T.D., Williams, A., Ahyong, S.T., Alderslade, P., Alvestad, T., Bray, D., Burghardt, I., Budaeva, N., Criscione, F., Crowther, A.L., Ekins, M., Eléaume, M., Farrelly, C.A., Finn, J.K., Georgieva, M.N., Graham, A., Gomon, M., Gowlett-Holmes, K., Gunton, L.M., Hallan, A., Hosie, A.M., Hutchings, P., Kise, H., Köhler, F., Konsgrud, J.A., Kupriyanova, E., Lu, C.C., Mackenzie, M., Mah, C., MacIntosh, H., Merrin, K.L., Miskelly, A., Mitchell, M.L., Moore, K., Murray, A., O'Loughlin, P.M., Paxton, H., Pogonoski, J.J., Staples, D., Watson, J.E., Wilson, R.S., Zhang, J., and Bax, N.J. (2020) The lower bathyal and abyssal seafloor fauna of eastern Australia. Marine Biodiversity Records 13(1), 11.

Olivera, B.M., Seger, J., Horvath, M.P., and Fedosov, A.E. (2015) Prey-Capture Strategies of Fish-Hunting Cone Snails: Behavior, Neurobiology and Evolution. Brain Behav Evol 86(1), 58-74. [In eng]

Puillandre, N., Brouillet, S., and Achaz, G. (2020) ASAP: Assemble Species by Automatic Partitioning. Molecular Ecology Resources.

Puillandre, N., Lambert, A., Brouillet, S., and Achaz, G. (2012a) ABGD, Automatic Barcode Gap Discovery for primary species delimitation. Molecular Ecology 21, 1864-1877.

Puillandre, N., Modica, M.V., Zhang, Y., Sirovich, L., Boisselier, M.C., Cruaud, C., Holford, M., and Samadi, S. (2012b) Large-scale species delimitation method for hyperdiverse groups. Molecular Ecology 21(11), 2671-2691.

Rambaut, A., Drummond, A.J., Xie, D., Baele, G., and Suchard, M.A. (2018) Posterior Summarization in Bayesian Phylogenetics Using Tracer 1.7. Systematic Biology 67(5), 901-904.

Rex, M.A., and Etter, R.J. (1998) Bathymetric patterns of body size: implications for deep-sea biodiversity. Deep Sea Research Part II: Topical Studies in Oceanography 45(1), $103-$ 127. 
Rex, M.A., Etter, R.J., Clain, A.J., and Hill, M.S. (1999) Bathymetric patterns of body size in deep-sea gastropods. Evolution 53(4), 1298-1301.

Ronquist, F., and Huelsenbeck, J.P. (2003) MrBayes 3: Bayesian phylogenetic inference under mixed models. Bioinformatics 19(12), 1572-1574.

Russini, V., Giannuzzi-Savelli, R., Pusateri, F., Prkic, J., Fassio, G., Modica, M.V., and Oliverio, M. (2020) Candidate cases of poecilogony in Neogastropoda: implications for the systematics of the genus Raphitoma Bellardi, 1847. Invertebrate Systematics 34(3), 293-318.

Saitou, N., and Nei, M. (1987) The neighbor-joining method: a new method for reconstructing phylogenetic trees. Molecular Biology and Evolution 4(4), 406-425.

Schepman, M.M. (1913) The Prosobranchia of the Siboga Expedition. Part V. Toxoglossa, with a supplement. Siboga-Expeditie 49, 365-452.

Shuto, T. (1971) Taxonomical notes on the turrids of the Siboga Collection originally described by M. M. Schepman, 1931 (Part 3). Venus Kyoto 30, 5-22.

Stahlschmidt, P., and Chino, M. (2012) A new species of Gymnobela (Gastropoda: Raphitomidae) from the Central Pacific. Miscellanea Malacologica 5, 95-98.

Sysoev, A.V. (1988) Ultra-abyssal findings of the family Turridae (Gastropoda, Toxoglossa) in the Pacific Ocean. Zoologicheskii Zhurnal 67(7), 965-973.

Sysoev, A.V. (1990) Gastropods of the family Turridae (Gastropoda: Toxoglossa) of the Nasca and Sala-y-Gomez underwater ridges. Trudy Instituta Okeanologii Akademii Nauk SSSR 124, 245-260.

Sysoev, A.V. (1996a) Deep-sea conoidean gastropods collected by the John Murray Expedition, 1933-34. Bulletin of the Natural History Museum Zoology Series 62(1), 130.

Sysoev, A.V. (1996b) Taxonomic notes on South African deep-sea conoidean gastropods (Gastropoda: Conoidea) described by K.H. Barnard, 1963. Nautilus 110(1), 22-29. Sysoev, A.V. (1997) Mollusca Gastropoda: new deep-water turrid gastropods (Conoidea) from eastern Indonesia. Mémoires du Museum National d'Histoire Naturelle 172 325-355.

Sysoev, A.V., and Bouchet, P. (2001) New and uncommon turriform gastropods (Gastropoda: Conoidea) from the South-West Pacific. Mémoires du Museum National d'Histoire Naturelle 185, 271-320. 
1288

1289

1290

1291

1292

1293

1294

1295

1296

1297

1298

1299

1300

1301

1302

1303

1304

1305

1306

1307

1308

1309

1310

1311

1312

1313

1314

Sysoev, A.V., and Ivanov, D.L. (1985) New taxa of the family Turridae (Gastropoda, Toxoglossa) from the Naska Ridge (south east Pacific). Zoologicheskii Zhurnal 64(2), 194-205. [In Russian]

Sysoev, A.V., and Kantor, Y.I. (1986) New and rare abyssal species of the family Turridae (Gastropoda, Toxoglossa) in the northern part of the Pacific Ocean. Zoologicheskii Zhurnal 65, 1457-1469. [In Russian]

Sysoev, A.V., and Kantor, Y.I. (1987) Three new species of the deep-sea mollusc genus Famelica (Gastropoda, Toxoglossa, Turridae). Zoologicheskii Zhurnal 66(8), 12551258.

Taylor, J.D. (1990) The anatomy of the foregut and relationships in the Terebridae. Malacologia 32(1), 19-34.

Taylor, J.D., Kantor, Y.I., and Sysoev, A.V. (1993) Foregut anatomy, feeding mechanisms, relationships and classification of the Conoidea (=Toxoglossa) (Gastropoda). Bulletin of the British Museum (Natural History) Zoology 59, 125-170.

Thistle, D., Yingst, J.Y., and Fauchald, K. (1985) A deep-sea benthic community exposed to strong near-bottom currents on the Scotian Rise (western Atlantic). Marine Geology 66(1), 91-112.

Verrill, A.E. (1884) Second Catalogue of Mollusca recently added to the Fauna of the New England coast. Transactions of the Connecticut Academy vi, pp. 139-294.

Watson, R.B. (1881) Mollusca of H.M.S. 'Challenger' Expedition.-Part IX. Journal of the Linnean Society of London, Zoology 15(88), 413-455.

Will, K.W., Mishler, B.D., and Wheeler, Q.D. (2005) The Perils of DNA Barcoding and the Need for Integrative Taxonomy. Systematic Biology 54(5), 844-851.

Williams, A. (2018) IN2018_V06. Status and recovery of deep-sea coral communities on seamounts in iconic Australian marine reserves., Hobart. 
Figure captions

Figure 1. Distribution of taxa studied herein with focus on the South West Pacific. (A) Records of sequenced specimens of Famelica (circles) and Glaciotomella (triangles). (B) Records of sequenced specimens of Rimosodaphnella (squares). The insets show records of Rimosodaphnella in off the coast of Chile (upper righolotype) and in the Tuamotu Archipelago (lower left). Numbers and letters in shapes indicate PSHs/species of: Famelica (circles: 1 -F1/F. turritelloides, 2-F2/F. acus, 3 -F3/F. tasmanica, 4 -F4/F. polyacantha, A - FA); Glaciotomella (1 - G1/G. investigator, 2 - G2/G. investigator, A - GA) and Rimosodaphnella (squares: $1-\mathrm{R} 1 / R$. guraradara, 2 - R2/R. truvana, 3-R3/R. solomonensis, $4-R 4 / R$. brunneolineata, $A-R A, B-R B, C-R C, D-R D, E-R E)$. Thin lines mark limits among marine realms (numbered as in Costello et al., 2017). Main scalebars $=1000 \mathrm{~km}$, insets scalebars $=200 \mathrm{Km}$.

Figure 2. Bayesian consensus phylogram (BI) based on analyses of cox1 sequences. Numbers above branches indicate nodal support by Bayesian posterior probabilities (BPP). Numbers below PSH nodes indicate nodal support (\%) by bootstrap (BS) resulting from the ML analysis of Fig. S1, with $100 \%$ values indicated by asterisks. Names of species described herein and sequences of Australian samples are in bold. Vertical bars mark distinct PSHs as delimited by ABGD on the corresponding cox1 dataset. Dashed rectangles mark alternative PSH groupings as delimited by the ASAP method. Symbols and numbers next to taxon names correspond to those used in Figure 1. Samples whose shells are figured are underlined. Scale bar (right) = $7.5 \mathrm{~mm}$ (shells of R3-R5, RB-RE, GA), $10 \mathrm{~mm}$ (other shells).

Figure 3. Protoconchs of species/PSHs studied here. (A) F2/F. acus n. sp. holotype MNHN IM- 2009-249221; (B) GA/G. sp. MNHN IM-2009-19042; (C) R5/R. brunneolineata, MNHN IM-2009-18977.

Figure 4. Shells of Famelica PSHs/species. (A) F1/F. turritelloides n. sp. holotype AMS C.482253; (B) F. catharinae (Verrill \& S. Smith [in Verrill], 1884) holotype USMN 37871; (C) F. pacifica Sysoev \& Kantor, 1987 holotype ZMMU LC 5369; (D) F. tasmanica Sysoev \& Kantor, 
1987 holotype ZMMU LC 5370; (E) F3/F. tasmanica AMS C.519370; (F) F3/F. tasmanica AMS

Figure 5. Shells of Famelica PSHs/species. (A) F. nitida Sysoev, 1990 holotype ZMMU LC 5737; (B) F. tajourensis Sysoev \& Kantor, 1987 holotype ZMMU LC 5371; (C) F2/F. acus n. sp. holotype MNHN IM- 2009-249221; (D) F2/F. acus n. sp. paratype SAMA D49339; (E) FA/F. sp. MNHN IM-2013-61627; (F) F4/F. polyacantha, MNHN IM-2009-17104; (G) F. polyacantha (Stahlschmidt, Chino \& Kilburn 2012) holotype NSMT Mo 78456. Scale bar $=10 \mathrm{~mm}$ (A-D, F$\mathrm{G)} ; 12.5 \mathrm{~mm}(\mathrm{E})$.

Figure 6. Shells of Glaciotomella and Neopleurotomoides PSHs/species. (A) G1/G. investigator Criscione et al. 2020 holotype AMS C.571621; (B) G2/G. investigator Criscione et al. 2020, SAMA D44120; (C) GA/G. sp. MNHN IM-2009-19042, (D) N. rufoapicatus (Schepman, 1913) holotype NMNL MOLL.136877. Scale bar $=10 \mathrm{~mm}$ (A-B), $5 \mathrm{~mm}$ (C), $4 \mathrm{~mm}$

Figure 7. Shells of Rimosodaphnella PSHs/species. (A) R1/R. guraradara n. sp., holotype AMS C.571613; (B) R1/R. guraradara n. sp., paratype AMS C.571684; (C) R1/R. guraradara n. sp., paratype AMS C.519332; (D) R2/R. truvana n. sp., holotype AMS C.571685; (E) R2/R. truvana n. sp., paratype AMS C.571615; (F) R2/R. truvana n. sp., paratype AMS C.571686; (G) RA/R. sp., MNHN IM-2013-57410; (H) R. deroyae n. sp., holotype LACM 1543; (I) R. textilis (Brocchi, 1814), holotype MSNMi 5340; (J) R. morra (Dall, 1881) holotype MCZ 7107. Scale bar = 10 $\mathrm{mm}(\mathrm{A}-\mathrm{H}), 7.5 \mathrm{~mm}(\mathrm{I}), 2.5 \mathrm{~mm}(\mathrm{~J})$.

Figure 8. Shells of Rimosodaphnella PSHs/species. (A) R. brunneolineata Bonfitto \& Morassi, 2013, holotype MZB 49760; (B) R5/R. brunneolineata, MNHN IM-2009-18977; (C) R4/ R. brunneolineata, MNHN IM-2007-42460; (D) R. solomonensis Bonfitto \& Morassi, 2013, holotype MNHN 25803; (E) R3/R. solomonensis Bonfitto \& Morassi, 2013, MNHN IM-200742524; (F) RB/R. sp., MNHN IM-2007-17836; (G) RC/R. sp., MNHN IM-2013-58315; (H) RD/R. sp., MNHN IM-2007-38690; (I) RE/R. sp., MNHN IM-2007-39365; (J) R. tenuipurpurata Bonfitto \& Morassi, 2013, holotype MZB 49758. Scale bar $=10 \mathrm{~mm}$. 
1378 Figure 9. Hypodermic radular teeth of Glaciotomella PSHs/species studied herein. (A)

1379 G1/Glaciotomella investigator Criscione et al., 2020 holotype AMS C.571621; (B)

1380 R2/Glaciotomella investigator Criscione et al. 2020, SAMA D44120. Scale bar $=100 \mu \mathrm{m}$. 1381

1382 Figure 10. Hypodermic radular teeth of Rimosodaphnella PSHs/species studied herein. (A) 1383 R1/Rimosodaphnella guraradara n. sp., paratype AMS C.519274; (B) R2/Rimosodaphnella 1384 truvana n. sp., paratype AMS C.571689. Scale bar $=50 \mu \mathrm{m}$.

1385

1386 Figure 11. Bathymetric ranges of PSHs/taxa studied herein as inferred from records of 1387 sequenced specimens. Species represented by a single record are indicated by a circle. 
1389 Tables captions

1390

1391 Table 1. Intra- and inter-PSHs/specific genetic differentiation of cox1 sequences in Famelica 1392 by means of $\mathrm{K} 2 \mathrm{p}$ distances. Intra-PSHs/specific distances shaded. Maximum and minimum 1393 values of inter-PSHs/specific distance in bold. Inset: minimum, maximum and average intra1394 and inter-PSHs/specific p-distances within Famelica. Species codes: acu, acus; pol, 1395 polyacantha; tas, tasmanica; tur, turritelloides. Codes of species described herein in bold. 1396

1397 Table 2. Intra- and inter-PSHs/specific genetic differentiation of cox1 sequences in 1398 Rimosodaphnella by means of K2p distances. Intra-PSHs/specific distances shaded.

1399 Maximum and minimum values of inter-PSHs/specific distance in bold. Inset: minimum, 1400 maximum and average intra- and inter-PSHs/specific $p$-distances within Rimosodaphnella. 1401 Species codes: bru, brunneolineata; gur, guraradara; sol, solomonensis; tru, truvana. Codes 1402 of species described herein in bold. 

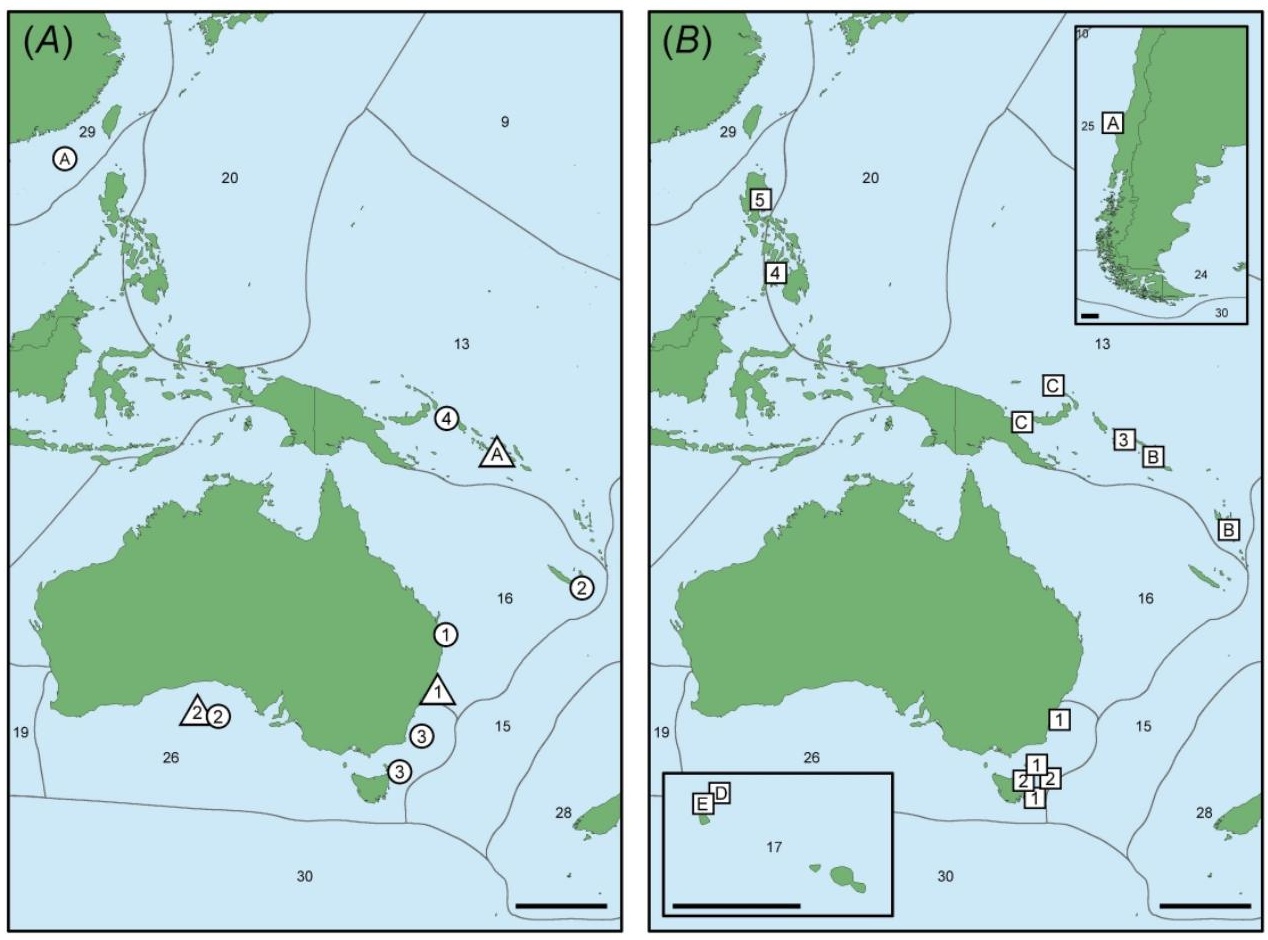

Distribution of taxa studied herein with focus on the South West Pacific. (A) Records of sequenced specimens of Famelica (circles) and Glaciotomella (triangles). (B) Records of sequenced specimens of Rimosodaphnella (squares). The insets show records of Rimosodaphnella in off the coast of Chile (upper righolotype) and in the Tuamotu Archipelago (lower left). Numbers and letters in shapes indicate

PSHs/species of: Famelica (circles: 1 - F1/F. turritelloides, 2 - F2/F. acus, 3 - F3/F. tasmanica, $4-F 4 / F$. polyacantha, A - FA); Glaciotomella (1 - G1/G. investigator, 2 - G2/G. investigator, A - GA) and

Rimosodaphnella (squares: 1 - R1/R. guraradara, $2-R 2 / R$. truvana, $3-R 3 / R$. solomonensis, $4-R 4 / R$. brunneolineata, A - RA, B - RB, C - RC, D - RD, E - RE). Thin lines mark limits among marine realms (numbered as in Costello et al., 2017). Main scalebars $=1000 \mathrm{~km}$, insets scalebars $=200 \mathrm{Km}$.

\section{$170 \times 126 \mathrm{~mm}(600 \times 600 \mathrm{DPI})$}




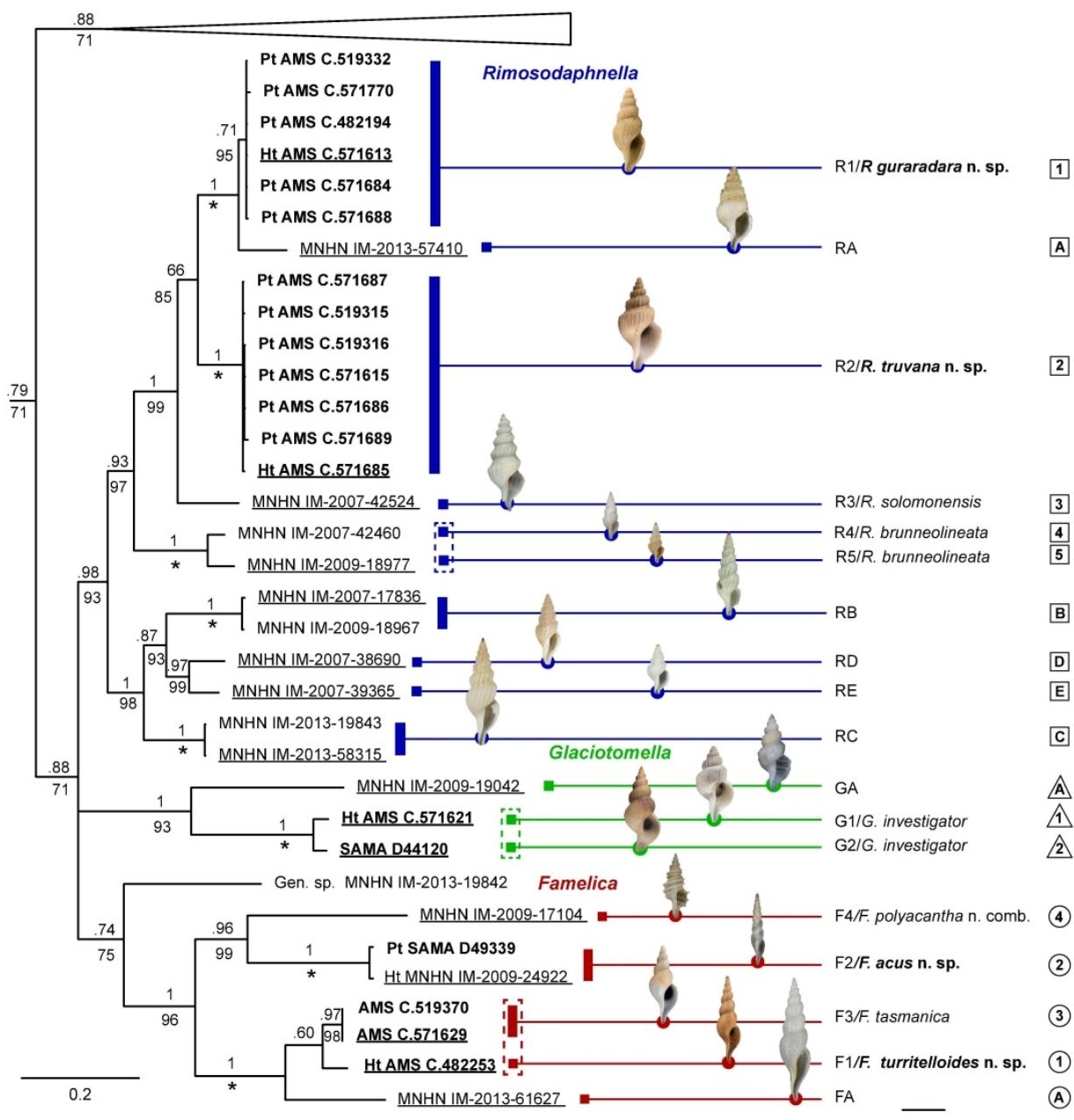

Bayesian consensus phylogram (BI) based on analyses of cox1 sequences. Numbers above branches indicate nodal support by Bayesian posterior probabilities (BPP). Numbers below PSH nodes indicate nodal support (\%) by bootstrap (BS) resulting from the ML analysis of Fig. S1, with $100 \%$ values indicated by asterisks. Names of species described herein and sequences of Australian samples are in bold. Vertical bars mark distinct PSHs as delimited by ABGD on the corresponding cox1 dataset. Dashed rectangles mark alternative PSH groupings as delimited by the ASAP method. Samples whose shells are figured are underlined. Scale bar (right) $=7.5 \mathrm{~mm}$ (shells of R3-R5, RB-RE, GA), $10 \mathrm{~mm}$ (other shells).

$168 \times 171 \mathrm{~mm}(600 \times 600 \mathrm{DPI})$ 


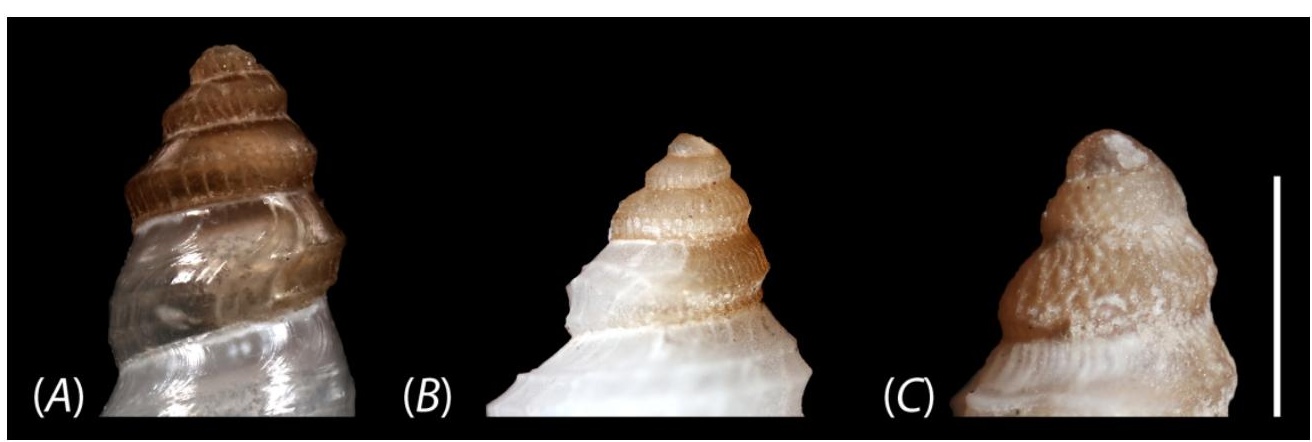

Figure 3. Protoconchs of species/PSHs studied here. (A) F2/F. acus n. sp. holotype MNHN IM- 2009-249221; (B) GA/G. sp. MNHN IM-2009-19042; (C) R5/R. brunneolineata, MNHN IM-2009-18977.

$199 \times 65 \mathrm{~mm}(300 \times 300 \mathrm{DPI})$ 


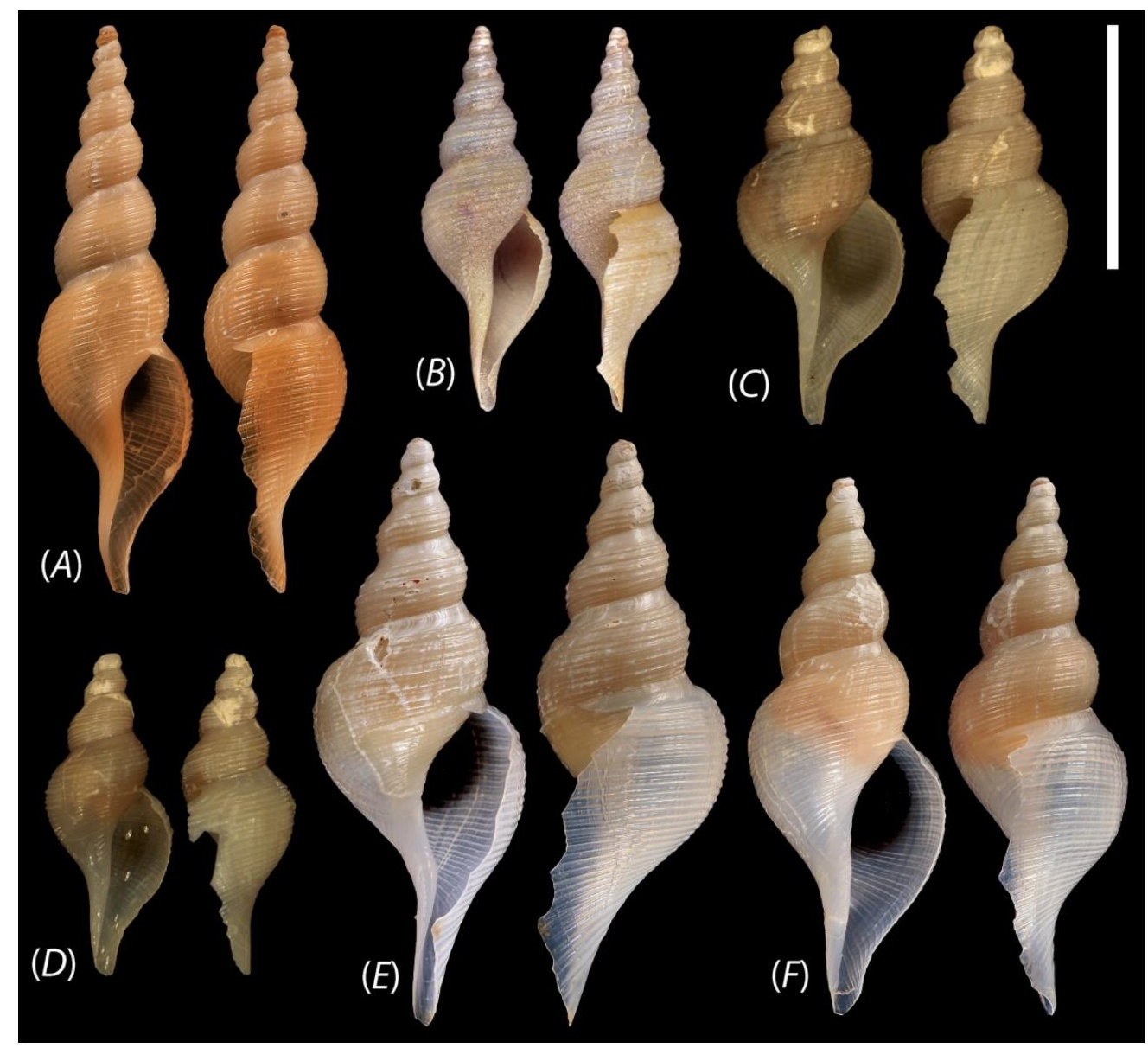

Figure 4. Shells of Famelica PSHs/species. (A) F1/F. turritelloides n. sp. holotype AMS C.482253; (B) F. catharinae (Verrill \& S. Smith [in Verrill], 1884) holotype USMN 37871; (C) F. pacifica Sysoev \& Kantor, 1987 holotype ZMMU LC 5369; (D) F. tasmanica Sysoev \& Kantor, 1987 holotype ZMMU LC 5370; (E) F3/F. tasmanica AMS C.519370; (F) F3/F. tasmanica AMS C.571629. Scale bar $=10 \mathrm{~mm}$. 


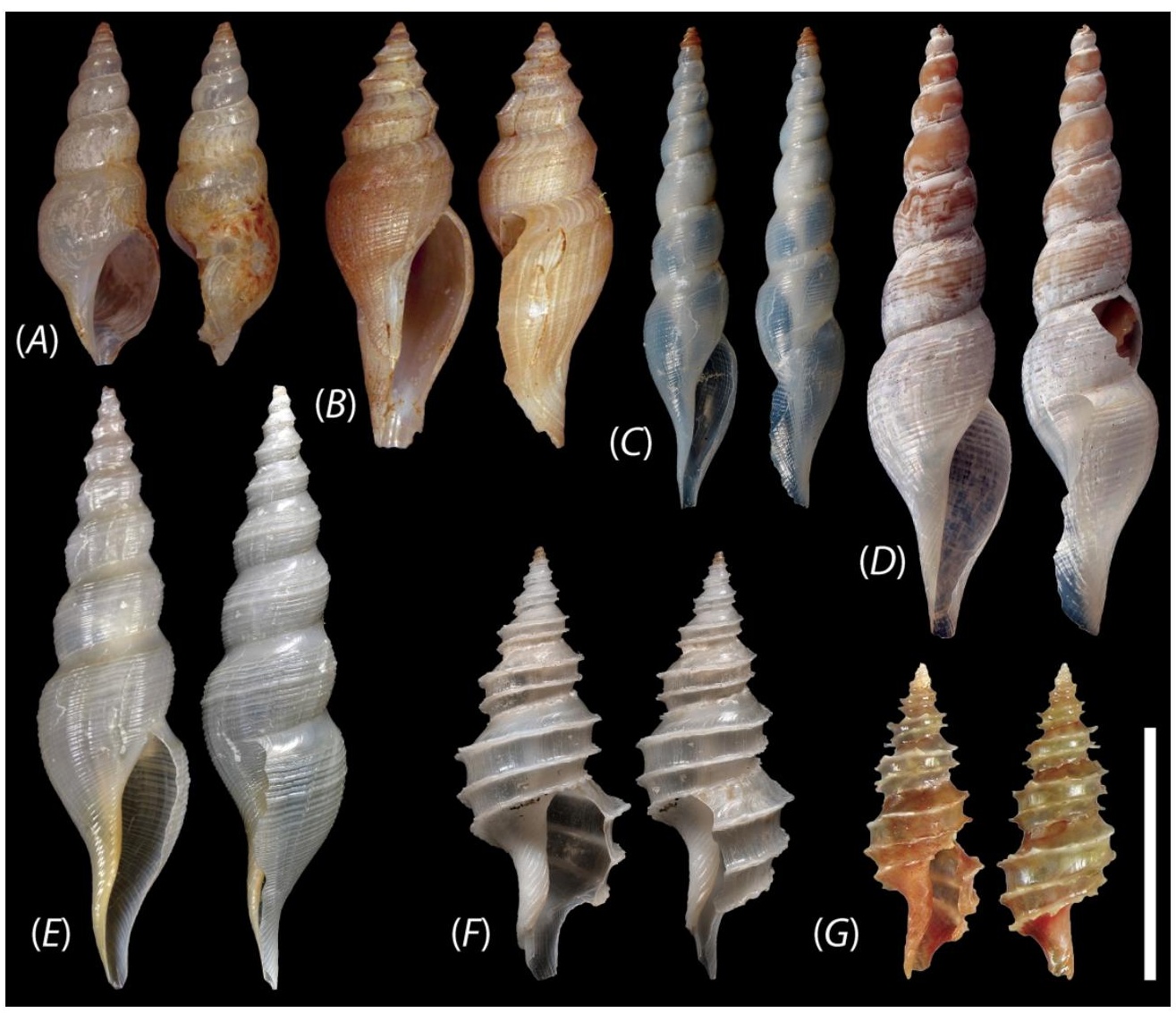

Figure 5. Shells of Famelica PSHs/species. (A) F. nitida Sysoev, 1990 holotype ZMMU LC 5737; (B) F. tajourensis Sysoev \& Kantor, 1987 holotype ZMMU LC 5371; (C) F2/F. acus n. sp. holotype MNHN IM- 2009249221; (D) F2/F. acus n. sp. paratype SAMA D49339; (E) FA/F. sp. MNHN IM-2013-61627; (F) F4/F. polyacantha, MNHN IM-2009-17104; (G) F. polyacantha (Stahlschmidt, Chino \& Kilburn 2012) holotype NSMT Mo 78456. Scale bar $=10 \mathrm{~mm}(A-D, F-G) ; 12.5 \mathrm{~mm}(E)$. 


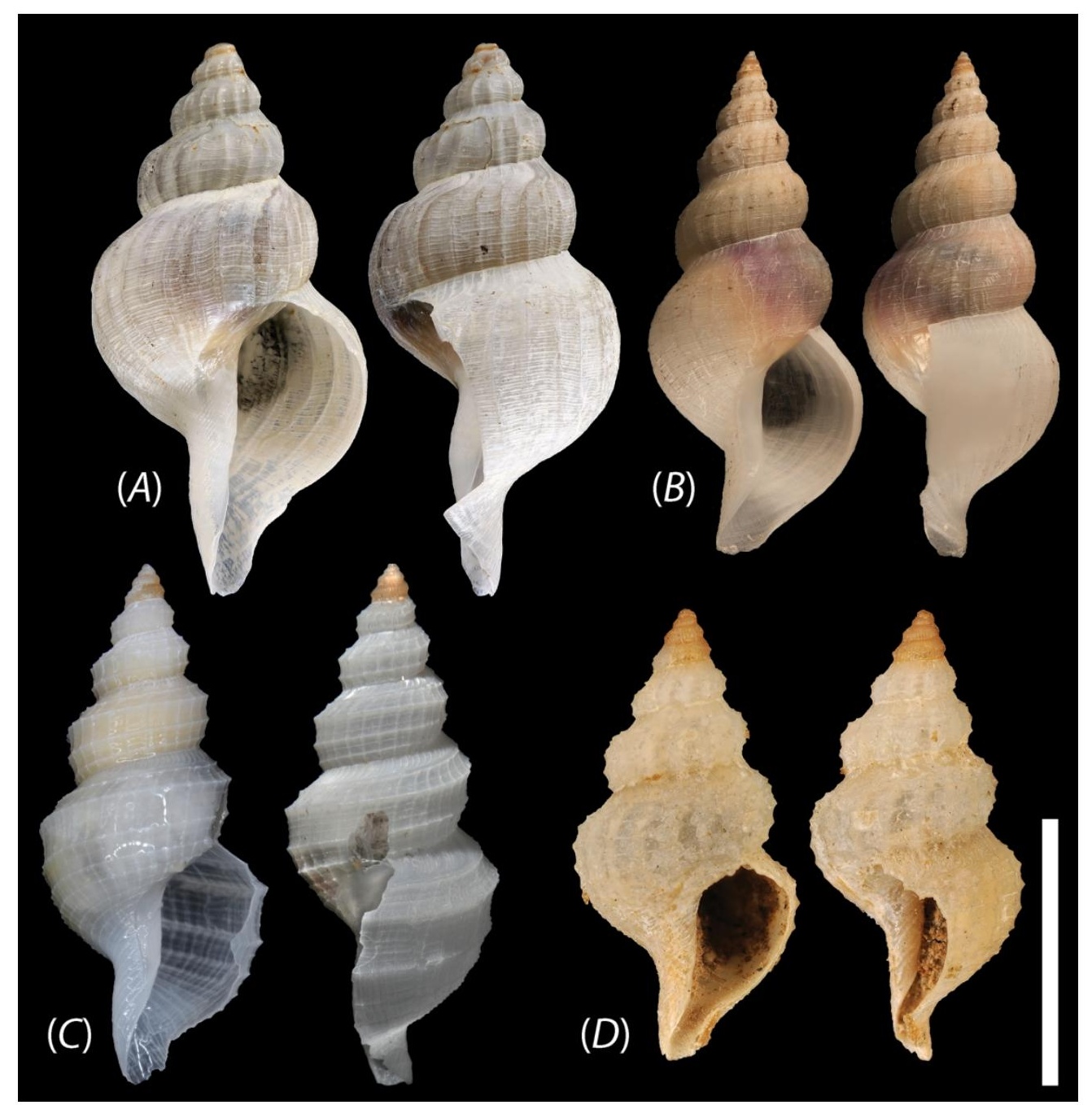

Figure 6. Shells of Glaciotomella and Neopleurotomoides PSHs/species. (A) G1/G. investigator Criscione et al. 2020 holotype AMS C.571621; (B) G2/G. investigator Criscione et al. 2020, SAMA D44120; (C) GA/G. sp. MNHN IM-2009-19042, (D) N. rufoapicatus (Schepman, 1913) holotype NMNL MOLL.136877. Scale bar = 10 $\mathrm{mm}(A-B), 5 \mathrm{~mm}(C), 4 \mathrm{~mm}(D)$. 


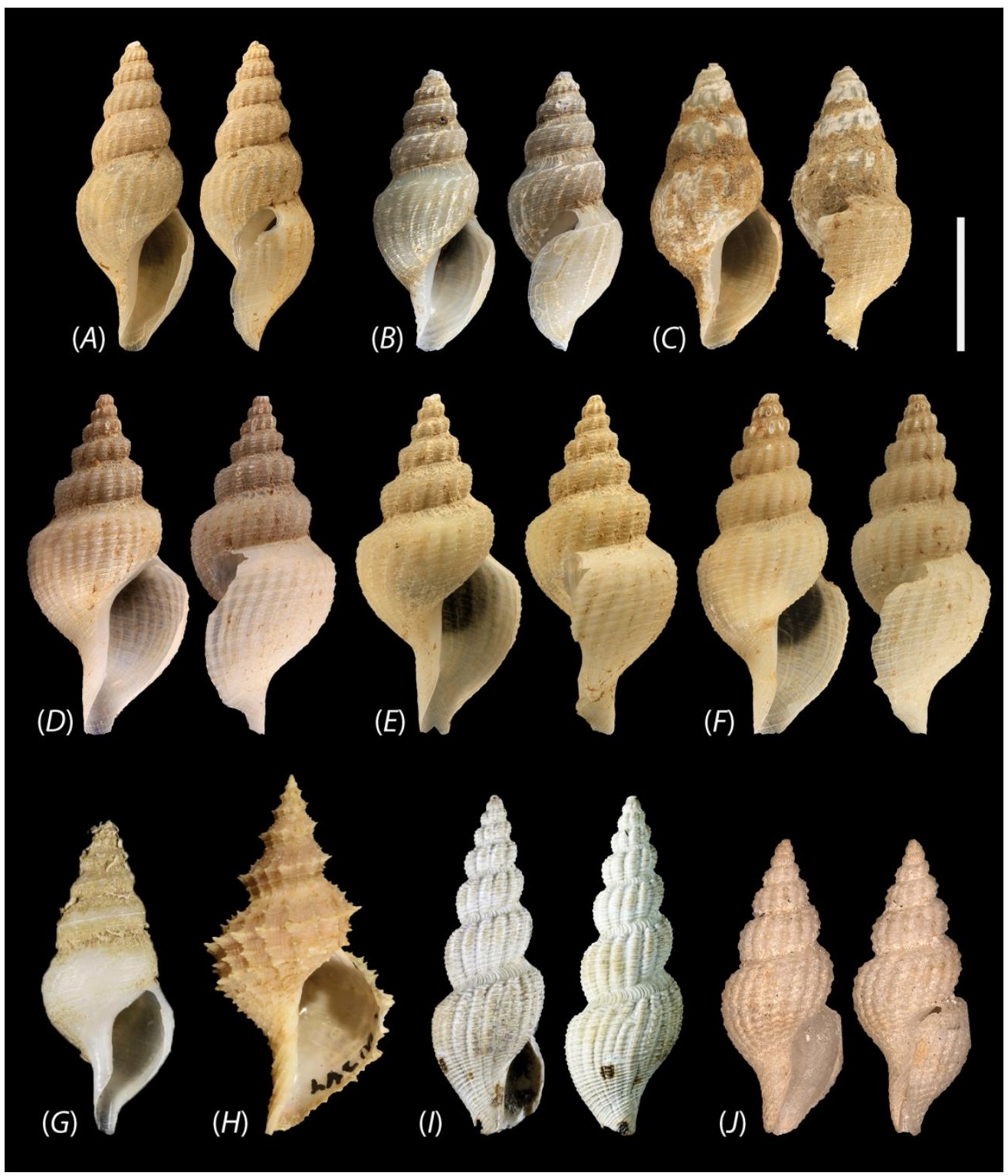

Figure 7. Shells of Rimosodaphnella PSHs/species. (A) R1/R. guraradara n. sp., holotype AMS C.571613; (B) R1/R. guraradara n. sp., paratype AMS C.571684; (C) R1/R. guraradara n. sp., paratype AMS C.519332;

(D) R2/R. truvana n. sp., holotype AMS C.571685; (E) R2/R. truvana n. sp., paratype AMS C.571615; (F)

R2/R. truvana n. sp., paratype AMS C.571686; (G) RA/R. sp., MNHN IM-2013-57410; (H) R. deroyae n. sp., holotype LACM 1543; (I) R. textilis (Brocchi, 1814), holotype MSNMi 5340; (J) R. morra (Dall, 1881) holotype MCZ 7107. Scale bar = $10 \mathrm{~mm}(\mathrm{~A}-\mathrm{H}), 7.5 \mathrm{~mm}(\mathrm{I}), 2.5 \mathrm{~mm}(\mathrm{~J})$. 


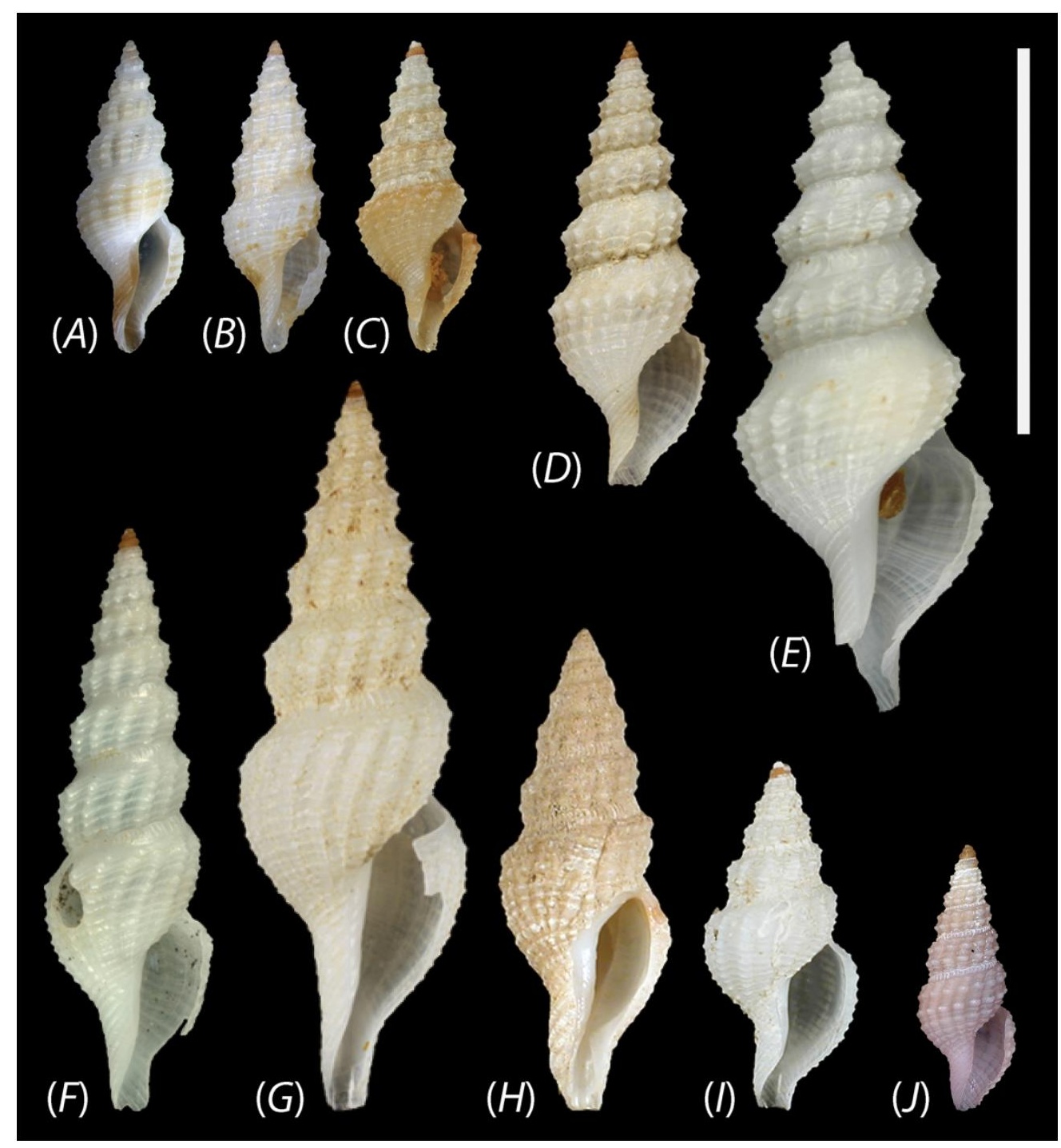

Figure 8. Shells of Rimosodaphnella PSHs/species. (A) R. brunneolineata Bonfitto \& Morassi, 2013, holotype MZB 49760; (B) R5/R. brunneolineata, MNHN IM-2009-18977; (C) R4/ R. brunneolineata, MNHN IM-200742460; (D) R. solomonensis Bonfitto \& Morassi, 2013, holotype MNHN 25803; (E) R3/R. solomonensis

Bonfitto \& Morassi, 2013, MNHN IM-2007-42524; (F) RB/R. sp., MNHN IM-2007-17836; (G) RC/R. sp., MNHN IM-2013-58315; (H) RD/R. sp., MNHN IM-2007-38690; (I) RE/R. sp., MNHN IM-2007-39365; (J) R. tenuipurpurata Bonfitto \& Morassi, 2013, holotype MZB 49758. Scale bar $=10 \mathrm{~mm}$. 


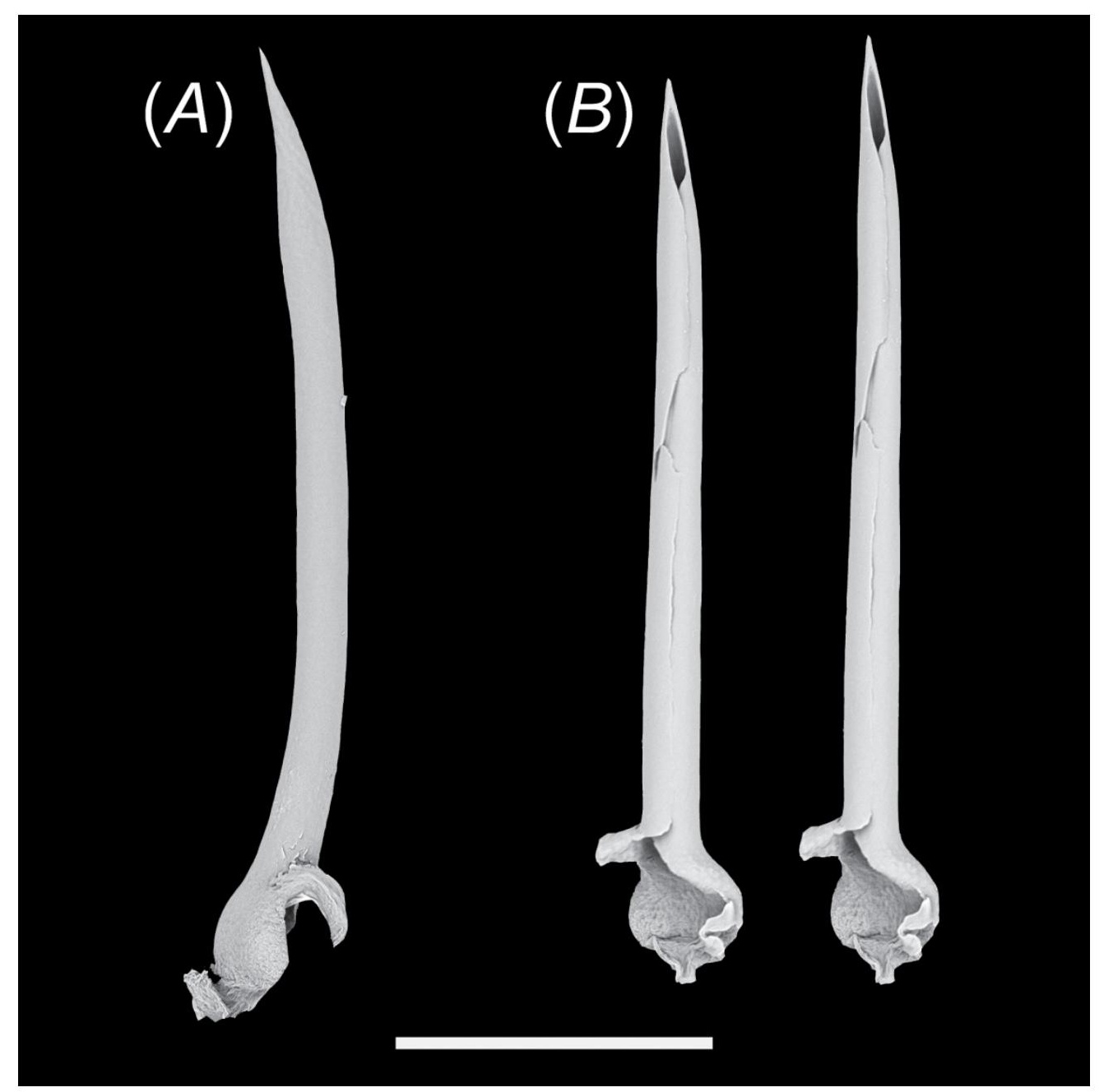

Figure 9. Hypodermic radular teeth of Glaciotomella PSHs/species studied herein. (A) G1/Glaciotomella investigator Criscione et al., 2020 holotype AMS C.571621; (B) R2/Glaciotomella investigator Criscione et al. 2020, SAMA D44120. Scale bar $=100 \mu \mathrm{m}$. 


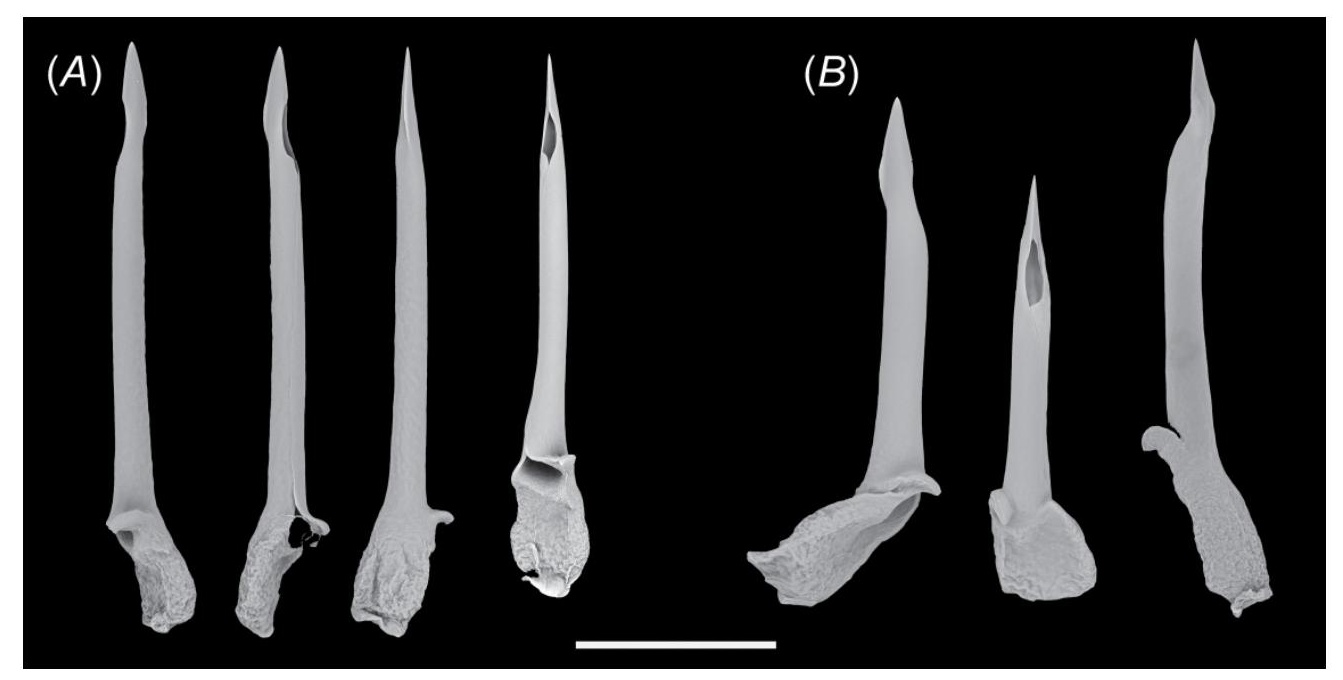

Figure 10. Hypodermic radular teeth of Rimosodaphnella PSHs/species studied herein. (A) R1/Rimosodaphnella guraradara n. sp., paratype AMS C.519274; (B) R2/Rimosodaphnella truvana n. sp., paratype AMS C.571689. Scale bar $=50 \mu \mathrm{m}$. 


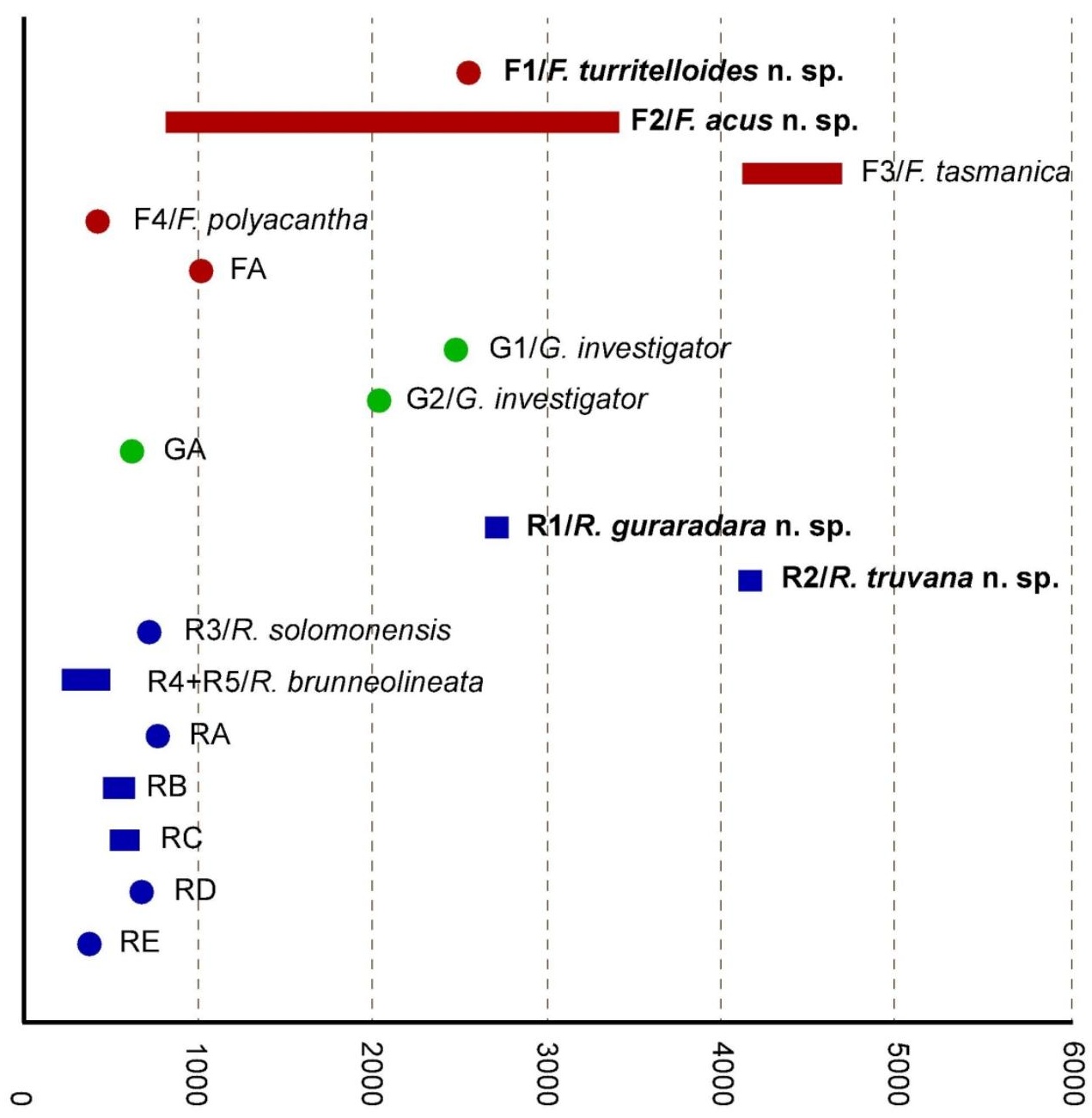

Figure 11. Bathymetric ranges of PSHs/taxa studied herein as inferred from records of sequenced specimens. Species represented by a single record are indicated by a circle.

$83 \times 84 \mathrm{~mm}(600 \times 600 \mathrm{DPI})$ 


\begin{tabular}{lccccccccc}
\hline & FA & F1/tur & F2/acu & F3/tas & F4/pol & & & & \\
\hline FA & - & & & & & & min & max & mean \\
\cline { 4 - 9 } F1/tur & 0.130 & - & & & & within & 0.008 & 0.008 & 0.008 \\
F2/acu & 0.171 & 0.169 & 0.008 & & & between & 0.052 & 0.182 & 0.145 \\
F3/tas & 0.129 & 0.052 & 0.154 & - & & & & & \\
F4/pol & 0.182 & 0.174 & 0.138 & 0.147 & - & & & & \\
\hline
\end{tabular}




\begin{tabular}{|c|c|c|c|c|c|c|c|c|c|c|}
\hline & R1/gur & R2/tru & RA & R3/sol & R4/bru & R5/bru & $\mathrm{RB}$ & $\mathrm{RC}$ & $\mathrm{RD}$ & $\mathrm{RE}$ \\
\hline R1/gur & 0.002 & & & & & & \multirow{6}{*}{$\begin{array}{l}\text { within } \\
\text { between }\end{array}$} & $\min$ & $\max$ & mean \\
\hline $\mathrm{R} 2 /$ tru & 0.093 & 0.003 & & & & & & 0.000 & 0.003 & 0.002 \\
\hline RA & 0.064 & 0.122 & - & & & & & 0.046 & 0.156 & 0.117 \\
\hline R3/sol & 0.092 & 0.098 & 0.117 & - & & & & & & \\
\hline R4/bru & 0.125 & 0.125 & 0.132 & 0.113 & - & & & & & \\
\hline R5/bru & 0.128 & 0.104 & 0.135 & 0.123 & 0.046 & - & & & & \\
\hline $\mathrm{RB}$ & 0.127 & 0.138 & 0.133 & 0.115 & 0.107 & 0.128 & - & & & \\
\hline $\mathrm{RC}$ & 0.141 & 0.136 & 0.156 & 0.126 & 0.122 & 0.132 & 0.102 & 0.003 & & \\
\hline $\mathrm{RD}$ & 0.147 & 0.141 & 0.141 & 0.131 & 0.129 & 0.127 & 0.092 & 0.098 & 0.000 & \\
\hline $\mathrm{RE}$ & 0.119 & 0.129 & 0.124 & 0.115 & 0.111 & 0.116 & 0.091 & 0.099 & 0.067 & - \\
\hline
\end{tabular}




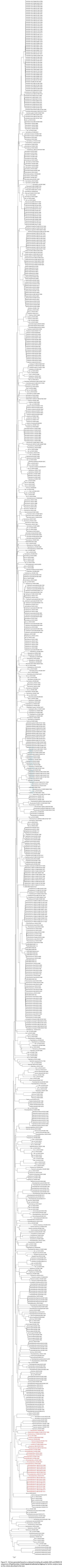




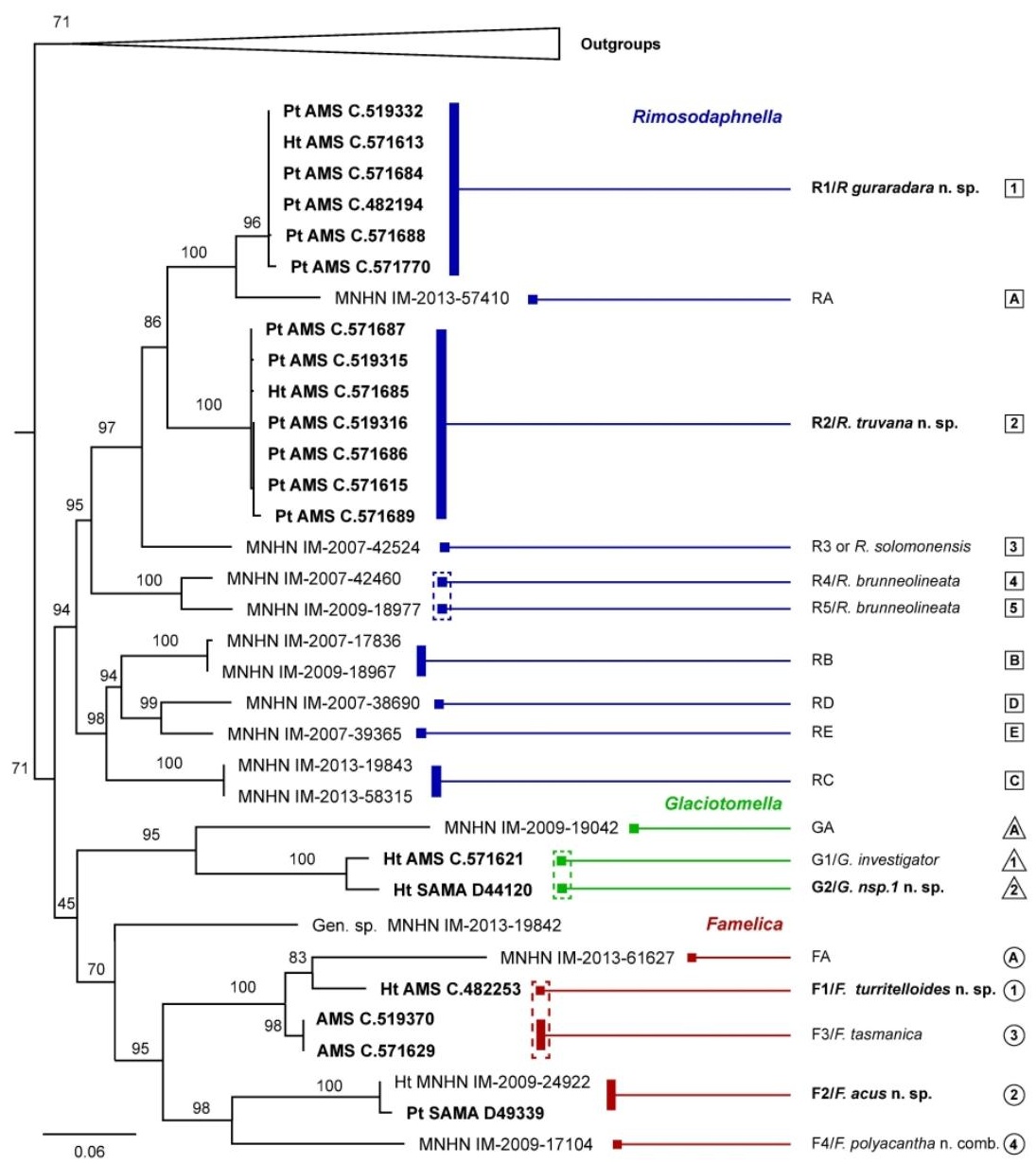

Figure S1. Maximum likelihood (ML) tree based on analyses of COI sequences. Numbers near branches indicate nodal support (\%) by ML bootstrap (BS). Support values for clades below the PSH/species level are omitted. Names of species described herein, and sequences of Australian samples are in bold. Vertical bars mark distinct primary species hypotheses (PSHs) as delimited by the ABGD method. Dashed rectangles mark alternative PSH groupings as delimited by the ASAP

method.

$168 \times 225 \mathrm{~mm}(600 \times 600 \mathrm{DPI})$ 